\title{
ELECCIONES GENERALES DEL 96. LA ARGUMENTACION NACIONALISTA EN EL PAIS VASCO
}

\author{
Ignacio María Beobide Ezpeleta
}

\section{Introducción}

Por séptima vez desde 1977 se celebraron en España Elecciones Generales a Cortes. Tuvieron lugar el día 3 de marzo de 1996. Triunfó por mayoría simple (el número de diputados del Congreso es de 375) el Partido Popular de José María Aznar, que obtuvo 156 diputados (9.658.688 votos $=38,85 \%$ ) y 111 senadores, y fue segundo el Partido Socialista Obrero Español con 141 diputados $(9.318 .600$ votos $=37,48 \%)$ y 81 senadores. El resto de diputados y senadores se distribuyeron entre Izquierda Unida y un grupo de Partidos nacionalistas y regionalistas según la siguiente tabla: Izquierda Unida, 21 diputados $(2.629 .847$ votos $=10,58 \%)$ y 0 senadores; CiU, 15 diputados $(1.144 .884$ votos $=4,61 \%)$ y 8 senadores; PNV, 5 diputados $(317.373$ votos $=1,28 \%)$ y 4 senadores; CC, 4 diputados $(220.069$ votos $=0,89 \%)$ y 2 senadores; BNG, 2 diputados (219.057 votos $=0,88 \%)$ y 0 senadores; HB, 2 diputados (180.979 votos $=0,73 \%)$ y 0 senadores; ERC, 1 diputado (166.917 votos $=0,67 \%)$ y 0 senadores; EA, 1 diputado $(115.512$ votos $=0,46 \%)$ y 0 senadores; UV, 1 diputado (91.350 votos $=0,37 \%)$ y 0 senadores; IF, 1 senador, y, por último, PIL, 1 senador ${ }^{1}$. La abstención fue de 21,94\%; los votos en blanco alcanzaron la cifra de 242.832 votos $(0,97 \%)$ y los votos nulos fueron $124.370(0,50 \%)$.

Por lo que se refiere al País Vasco, Comunidad Autónoma Vasca, los resultados fueron los siguientes:

La composición total de la Cámara Alta incluye, además de los resultados citados, los senadores designados por los Parlamentos Autonómicos, cuestión que no importa para este trabajo. 


\begin{tabular}{lccc}
\hline & N.o votos & $\%$ & Escaños \\
\hline PNV & 314.228 & $25,05 \%$ & 5 \\
PSE-PSOE & 295.485 & $23,56 \%$ & 5 \\
PP & 229.897 & $18,33 \%$ & 5 \\
HB & 154.286 & $12,30 \%$ & 2 \\
IU & 115.805 & $9,23 \%$ & 1 \\
EA & 103.252 & $8,23 \%$ & 1 \\
ICV & 11.798 & $0,94 \%$ & 0 \\
\hline
\end{tabular}

El PSE-PSOE sacó 5 senadores; el PNV, 4 y el PP, 3. La abstención en el País Vasco alcanzó el 28,15\%².

El total de votos nacionalistas alcanzó la cifra de 571.776, el 47,1\%, mientras que los votos a Partidos de ámbito general fueron 641.187, el $52,86 \%{ }^{3}$.

Según esto, por primera vez desde las Elecciones Generales de 1977, en las que el nacionalismo vasco no fue la primera fuerza política, el voto a los Partidos Socialista, Popular e Izquierda Unida ha superado en más de cinco puntos al voto nacionalista del PNV, EA y HB aumentando la notable mejoría ya observada en las Generales de 1993, cuando se quedaron a un solo punto. Los 8 diputados nacionalistas frente a los 11 de los primeros confirman la misma conclusión. Lo mismo cabe decir del número de senadores obtenidos.

Este trabajo pretende analizar la campaña electoral de los Partidos nacionalistas vascos, que precedió a semejantes resultados. El análisis pretende mostrar tanto cuantitativa como cualitativamente las argumentaciones utilizadas en la petición del voto al electorado vasco según una estructura y unas fuentes ya utilizadas en anteriores análisis ${ }^{4}$.

El análisis utiliza como fuente la prensa diaria en su vertiente informativa (mítines, conferencias de prensa, entrevistas, declaraciones de los políticos de un Partido) y deja de lado la vertiente de opinión del propio

2 Los datos están tomados de El Correo 5-3-96, «Especial Elecciones 96», y de la Edición extraordinaria, «Elecciones Generales, Crónica n. ${ }^{\circ}$ 732» de Vasco Press del 4 de marzo de 1996.

${ }^{3}$ No se tienen en cuenta los 11.798 votos de ICV de José María Gorordo, que ni era una agrupación nacionalista ni tampoco un Partido de ámbito general.

${ }_{4}$ Ver mis trabajos en: Estudios de Deusto, vol. 42/2, julio-diciembre 1994, «Elecciones al Parlamento Vasco del 23 de octubre de 1994», pp. 11-76; Estudios de Deusto, vol. 41/2, julio-diciembre 1993, «Elecciones generales del 6 de junio de 1993. La campaña de los Partidos Nacionalistas Vascos», pp. 9-65 y los anteriores trabajos citados en p. 9.

Los números entre paréntesis, que siguen a la fecha de cada periódico, se refieren a la página o páginas del mismo. 
periódico o del periodista. Los periódicos utilizados son los de mayor difusión en el área de Bilbao, en concreto, El Correo (El Correo EspañolEl Pueblo Vasco), Deia, Egin, El Mundo del País Vasco y El País. Ello hace que la información sea más abundante sobre lo ocurrido en Bizkaia que en otros Territorios Históricos, lo cual afecta a determinadas cuestiones tales como la identificación de los políticos actuantes en las campañas o la cuantía de su participación.

Por razones de uniformidad y por el hecho de que Eusko Alkartasuna carece de periódico propio, a diferencia del PNV y Herri Batasuna, que cuentan con Deia y Egin respectivamente, la cuantificación de los datos se ha realizado siguiendo las aportaciones de El Correo. Según esto, del total de unidades informativas de la campaña nacionalista, $3.274^{5}, 1.410$ corresponden al PNV, o sea, el 43,06\%, 1.229 (37,53\%) corresponden a Eusko Alkartasuna y $635(19,39 \%)$ corresponden a Herri Batasuna. Tomando la información del PNV como unidad de base, 100, la información de EA alcanza un valor de 87,16, mientras que la de HB sólo llega a 44,32 . Esta diferencia en la información cuantitativa, que no cualitativa, es muy inferior a la que establecen los periódicos Deia y Egin.

En buena medida las campañas de las Elecciones Generales de 1996 son una repetición de las de 1993, también Generales, con algunas modificaciones, consecuencia de determinados cambios coyunturales. Se repitieron planteamientos, contenidos y hasta expresiones. Por ello, bastante de lo dicho en torno a aquellas elecciones ha de repetirse en las de marzo del 96.

El PNV desarrolló una campaña muy poco nacionalista tanto cuantitativa como cualitativamente. Esta afirmación ha de entenderse de acuerdo con la estructura básica relacional de todo nacionalismo, que supone el binomio de la autoafirmación de la propia identidad política y el rechazo del «otro», consecuencia de la identidad-diferencia, afirmaciónnegación, independencia-separación de la mitología nacionalista. El argumento nacionalista en la petición del voto fue muy reducido en su versión «positiva» de definición de la identidad política. No alcanzó el $5 \%$ de la campaña, pero fue suficiente para dejar constancia de la variedad de objetivos a corto y a largo plazo y de la incertidumbre de la primacía entre ellos. Estatuto, autogobierno, foralismo, Estado asimétrico, Estado confederal, autodependencia, autodeterminación y soberanía fueron los conceptos utilizados. Algunos de ellos sólo aparecieron en entrevistas del periódico Deia, lo que sugiere un destino de consumo interno. Sin

5 Por unidad informativa se entiende cada línea del periódico, en general citas textuales de los sujetos actuantes, dedicada a informar sobre las cuestiones que son objeto de análisis de este trabajo, de donde, por ello, se excluyen los artículos de comentario, los editoriales, los artículos de opinión, los datos de las encuestas y la propaganda. 
embargo, la versión negativa del nacionalismo orientada a la descalificación, denuncia y rechazo del «enemigo», del «otro», del «opresor», que electoralmente se identificó, bastantes veces, con el competidor electoral, fue muy importante. Aquí hay que incluir los ataques a la Constitución por no reconocer el derecho de autodeterminación, la denuncia de su «déficit» democrático, los vicios de la democracia actual, el encorsetamiento constitucional, las amenazas constitucionales de intervención militar o la explicación de la violencia por problemas políticos previos. La propaganda nacionalista casi ni mencionó el objetivo de la independencia, pero denunció que no se permitiese lograrla democráticamente.

La campaña fue nacionalista, porque utilizó expresa o veladamente el argumento del enfrentamiento entre lo vasco y lo español, que se concretó especialmente en la crítica al Partido Popular y al PSOE, presentados como los enemigos de los intereses vascos, y porque, asimismo, intentó deslegitimar las otras opciones nacionalistas, bien por usar la violencia en el caso de ETA-HB o bien por dividir el nacionalismo democrático en el caso de EA, con el consiguiente perjuicio para la causa del nacionalismo vasco.

Esta idea recorre toda la campaña, la idea de que el PNV encarna y representa la legitimidad vasca y los intereses vascos, ante lo cual HBETA es una vergüenza, EA una inutilidad y el PP y el PSOE los apaleadores de lo vasco ${ }^{6}$.

No obstante todo lo dicho, el PNV se centró sobre el Partido Popular. Entre lo dedicado a criticarlo y lo dedicado a exponer un posible entendimiento de Legislatura con él se alcanzó casi la mitad de los contenidos de la campaña. Estaba en juego la participación en el poder, el aumento de poder. En buena medida la campaña del PNV fue un intento de justificación tanto de un posible entendimiento, pacto o acuerdo de Legislatura con el Partido Popular, del que no se esperaba desde las filas nacionalistas una victoria por mayoría absoluta, como de su posible fracaso. Los argumentos utilizados tenían en cuenta el interés general, concretado en la estabilidad de Gobierno para toda España, y el interés particular de Euskadi concretado, entre otras razones, en la garantía de la permanencia del Estado de Bienestar y en el desarrollo del Estatuto.

Esta campaña interpreta que la sociedad vasca es lo suficientemente plural como para no poder digerir un discurso absoluta y positivamente nacionalista en la petición del voto. La campaña fue «negativamente» nacionalista, lo cual encaja con la intención de aumentar las cotas de poder, ya que en ese caso el nacionalismo actúa como lector de un «cuaderno de agravios», que lo mismo incluye entre éstos el rechazo del derecho de

\footnotetext{
${ }^{6}$ El término «apaleador» sólo se dijo de la derecha española, pero las acusaciones fueron las mismas, aunque con distinta intensidad.
} 
autodeterminación que el desmantelamiento industrial. Hubo espacio para otros contenidos y argumentos, entre los que destacó el tema de la violencia, como corresponde a un Partido con pretensiones de participación en el poder, pero no fueron el eje de la campaña.

La campaña de Eusko Alkartasuna expresamente reconoció la enorme dificultad que había en que la sociedad vasca aceptase los contenidos fundamentales de la ideología nacionalista. No sólo se reconocía la división y la fractura de la realidad vasca, sino su blindaje. Ello sólo ya da cuenta de la existencia de dos nacionalismos, el de oferta, que hace un Partido, y el social, que es el definitivo en un comportamiento democrático, distinción que maneja con soltura el Partido Nacionalista. Por su parte, EA desarrolló una campaña, en la que los componentes positivos nacionalistas — siendo la independencia el objetivo final- fueron importantes cuantitativamente hablando, ya que alcanzaron casi una quinta parte de la campaña. Hubo una reiterada afirmación positiva de nacionalismo vasco, presentado como un derecho, como la solución de los problemas de los vascos y como un proyecto integrador dirigido a todos los vascos, que, si bien tenía el lado positivo de no excluir a nadie, tenía el lado negativo de incluir a todos. Esta insistencia electoral resalta más, si se tiene en cuenta la dificultad social inicial. Ahora bien, por encima del nacionalismo en cuanto ideología se sitúan la defensa de los derechos humanos y el respeto a la voluntad democrática de los vascos, que se presenta como criterio del desarrollo gradual y lineal desde la autonomía hasta la independencia. Completa esta versión del nacionalismo la llamada a superar la violencia y la búsqueda interesada de cotas de poder para integrar en el futuro la unión de los nacionalistas frente a la unión de los antinacionalistas.

La versión «negativa» del nacionalismo existió, pero apenas tuvo incidencia cuantitativa con respecto al «enemigo» externo, aunque, por supuesto, se defendió el origen político de la violencia y se calificó al Partido Popular y al PSOE como los Partidos «del otro lado» y como los Partidos antivascos. La descalificación del «otro» recayó en el Partido Nacionalista y en Herri Batasuna por sus servidumbres al poder y olvido de la causa nacionalista, en el primero, y por su violencia, en el segundo. EA no puso en cuestión la legitimidad nacionalista de ambos con las rectificaciones oportunas. Ahora bien, la suma de los espacios dedicados contra el PNV y HB con lo dedicado a la presentación positiva del nacionalismo superó el $60 \%$ del total de la campaña. Si se tiene en cuenta, además, que buena parte de la campaña, como ocurrió en la del PNV, la acaparó el tema de la violencia, se entiende que haya poco espacio para otras argumentaciones. El ámbito político electoral de EA era mucho más restringido que el del PNV. 
La cuestión de poder no aparece en la campaña más que como crítica al modo de buscarlo y conseguirlo el PNV, lo que constituyó una notable diferencia con la campaña de 1993, en la que tratándose de unas Elecciones Generales EA intentó unos resultados electorales que le permitiesen derribar la coalición de Gobierno autonómico formada por el PNV y el PSOE para establecer un Gobierno nacionalista. La política o estrategia de Legislatura casi no existió.

La campaña de Herri Batasuna muestra una confianza absoluta y desmesurada en la capacidad de movilización de la ideología nacionalista y en su capacidad de legitimación. Cuantitativamente superó el $40 \%$ de los contenidos, en los que clara y rotundamente, de principio a fin de la campaña, se defendió la necesidad de la inmediata independencia de Euskadi. En ella estaba la solución de todos los problemas desde los sociales y económicos hasta el de los presos y el de la violencia. Unida esta formulación «positiva» a la negación expresa de todo lo español - y francés-, de su Constitución, sistema político, democracia, Partidos y modelo social, y a la denuncia del colaboracionismo del PNV y EA, resulta que apenas se dejó algún resquicio para otra cosa que no fuera el nacionalismo.

No se incluye en este estudio al ICV de José María Gorordo, porque ni era propiamente partido, ni era nacionalista, ni tenía ideología, sino únicamente ideas, según declaraciones del propio Gorordo 7 .

El análisis de cada campaña nacionalista que sigue a esta Introducción se desarrolla según una misma estructura: datos básicos o generales y desarrollo de la campaña, distinguiendo la imagen o identidad de Partido (según el contenido nacionalista, según otros argumentos programáticos y según la política de Legislatura) y la crítica a los demás Partidos Políticos.

\section{La campaña del Partido Nacionalista Vasco}

\section{Datos básicos}

El 46,18\% de la campaña estuvo orientado a crear la identidad o imagen electoral del PNV y el 53,82\% de la misma pretendió criticar y desprestigiar las opciones de los demás Partidos políticos. Dentro de la primera parte, la identidad del Partido, el nacionalismo, es decir, los temas estrictamente nacionalistas o afines al nacionalismo como el Estatuto (que objetivamente no lo es) ocuparon el 10,44\%, que en el total de la campaña representó el 4,82\%. Autogobierno, autonomía, autodependencia, Estado

\footnotetext{
7 Ver El Mundo del País Vasco 16-2-96 (34).
} 
confederal, soberanía, además de alguna vaga alusión a la autodeterminación, fueron los contenidos de este leve recurso electoral al nacionalismo.

Mayor importancia electoral se dio a los temas no nacionalistas, como fueron el modelo de sociedad, el rechazo de la violencia, la educación para la paz, la defensa de la aplicación de la ley, el Pacto de Ajuria Enea, la eficacia de la gestión nacionalista o la política industrial. Todos ellos ocuparon el 59,75\% de la Imagen de Partido y el 27,58\% del total de la campaña. En realidad hubo un tema que dominó en buena medida este apartado y éste fue el de la paz y el terrorismo, como después se podrá ver en el desarrollo de la campaña.

Los posibles pactos postelectorales con el Partido Popular fueron el contenido del tercer apartado de esta primera parte, el relativo a la estrategia a seguir de apoyo u oposición al futuro Gobierno, que alcanzó el $31,33 \%$ de la Imagen y el $14,46 \%$ del total de la campaña.

La segunda parte de la campaña tuvo un destinatario principal, el Partido Popular. El acaparó el 62,31\% de la crítica a los Partidos y el 33,54\% del total de la campaña. El tándem Herri Batasuna-ETA ocupó el 23,45\% y el $12,62 \%$, respectivamente. El Partido Socialista-Euskadiko Eskerra el $11,06 \%$ y el $5,95 \%$, siendo inapreciables las alusiones a Izquierda Unida y la crítica general a los Partidos. Si bien lo que se dijo de Eusko Alkartasuna fue poco, el mensaje contenía, sin embargo, graves acusaciones.

La participación de los políticos fue muy desigual. Arzalluz, con el 43,12\%, fue el más activo. A continuación vinieron Anasagasti con el $31,16 \%$, González de Txabarri con el 8,16\%, Ardanza con el 7,73\%, Egibar con el 7,52\% y Albistur y Ollora con participaciones insignificantes. A éstos hay que añadir las intervenciones de Jon Zabalia, Emilio Olabarría, Pello Caballero y Jon Gangoiti en entrevistas del diario Deia, que no alteran prácticamente la tasa de intervención en la campaña, ya que en el diario del PNV y en otros periódicos (El Mundo del País Vasco, El País) también se recogen otras entrevistas como las realizadas a González de Txabarri, I. Anasagasti y Arzalluz. Unicamente, tal vez, Olabarría tuvo una participación mayor.

\section{El desarrollo de la campaña}

A) La imagen del Partido

\section{El contenido nacionalista}

Desde la presentación del programa electoral se advirtió que el PNV no utilizaría en la campaña, salvo en contadas ocasiones, el tema del derecho de autodeterminación. La autodeterminación no era un mensaje 
realista. El realismo lo constituían el desarrollo del Estatuto y la defensa del Estado de Bienestar. La autodeterminación habría de llegar, pero «no en los próximos cuatro años» ${ }^{8}$. Había que dejar constancia de que el nacionalismo del PNV incluía la autodeterminación, pero no convenía airearla demasiado. Importaba más destacar que España (el Estado español) no permitía en su Constitución el ejercicio de la autodeterminación (lo que constituía una carencia importante de democracia) que apoyarla constantemente. Con ello se satisfacían varios objetivos: la identificación nacionalista del Partido, su diferenciación con respecto a los otros partidos nacionalistas, la moderación ante el electorado no nacionalista y, muy especialmente, la presentación del pueblo vasco como víctima de la opresión española, que impedía el ejercicio de su libertad nacional. El argumento era plenamente nacionalista, pero la promesa de su marginación de la campaña sugería la poca confianza que se tenía en su capacidad recaudatoria de votos.

El programa nacionalista destacaba que «...aun participando en un sistema de libertades, existe en el Estado español un importante déficit democrático, cual es que, garantizándose la libre defensa de ideales y objetivos políticos, se imposibilita de facto su aplicación en virtud del encorsetamiento constitucional. Es decir, se puede ser nacionalista vasco y persuadir a la mayoría de los vascos para que apoyen un supuesto ejercicio de autodeterminación, pero la Constitución, a través de sus artículos segundo y octavo, cierra cualquier puerta a este supuesto bajo la amenaza de intervención militar» ${ }^{9}$.

Esta argumentación nacionalista, que presenta al «otro» como el causante de los males de la propia nación, se repitió sin ningún tipo de distinción histórica o circunstancial al «reconocer que ETA es una respuesta a la violencia franquista, de negación de principios democráticos y de

8 Afirmación de Arzalluz en El Correo 16-2-96 (25), que repetía las hechas en las Elecciones Generales del 93. Ver también Deia 16-2-96 (10), donde Arzalluz declara la «concepción realista» de la política del PNV y su creencia de que en cuatro años no habrá ningún pronunciamiento nuevo sobre la autodeterminación. Ver, también, El País 16-2-96 (21). En Deia 26-2-96 (4), Anasagasti resumió las propuestas programáticas en: Influir en las decisiones de la UE, desarrollo del Estatuto, cohesión social para eliminar el paro, la paz y formacion y educación para una sociedad tolerante. Ver, así mismo, Egin 16-2-96 (3) y 19-2-96 (9), donde se recoge información de supuestos documentos del grupo de campaña del PNV, en los que se justificaba esta estrategia por razones puramente electorales orientadas a captar el voto de la extinta UCD de Suárez. En Deia 18-2-96 (10) se recoge un resumen de la «Ponencia Política del PNV», todavía sin publicar, aprobada en su última Asamblea General de diciembre de 1995, que no se utiliza en este trabajo, porque, entre otras razones y tal como lo dice la propia Ponencia, «nada de lo que aquí se dice es nuevo».

9 El Correo 16-2-96 (25), «Programa electoral del PNV». 
prácticas de terrorismo de Estado que debieran comportar depuraciones judiciales y políticas» ${ }^{10}$.

Si la autodeterminación no iba a sufrir cambios en los cuatro años siguientes a las elecciones, la independencia del pueblo vasco se conseguiría antes de cien años. Así se lo hizo saber el Presidente del PNV a los militantes de EGI, la organización juvenil del Partido Nacionalista, cuando éstos lo recibieron en la tribuna del pabellón de La Casilla en el mitin final de la campaña al grito de «independentzia, independentzia» ${ }^{11}$.

La campaña fue muy pobre en contenidos nacionalistas. Se cumplió el silencio sobre la autodeterminación, aunque parece que Emilio Olabarría se salió del guión, al responder a las declaraciones de Aznar sobre la autodeterminación que era irrelevante que la Constitución no la reconociese y normal que no creyese en ella Aznar, ya que se trataba de un nacionalista español. Olabarría, por su parte, repitiendo disparates habituales entre algunos nacionalistas, añadió que «no creer en la autodeterminación es imposible, porque es un derecho humano y su titular son los pueblos; los mecanismos y el tiempo de ejercicio son otras cuestiones que habría que consensuar y que en este momento están inmaduras. Nadie puede decir que no cree en el derecho de autodeterminación porque es como el derecho a la vida, es un derecho humano, asociado a la dignidad de cualquier pueblo. El hecho de que la Constitución no lo reconozca es algo irrelevante, porque es un derecho anterior al texto constitucional» 12 .

Casi al final de la campaña Arzalluz ratificó lo que parecía el planteamiento inicial sobre la autodeterminación al decir que «la autodeterminación como derecho ya está clavada en el Parlamento Vasco. ¿Para cuándo? Pues no lo sé, pero yo no entraría en ese camino mientras haya violencia» ${ }^{13}$.

La autonomía, por su parte, fue también poco tratada, y se utilizó principalmente como argumento crítico contra los grandes Partidos — del Partido Popular se dijo que se oponía al Concierto Económico «por su

10 El Correo 16-2-96 (25).

11 El Correo 2-3-96 (21), donde el cronista traduce al castellano la frase de Arzalluz dicha en euskera: «Seguid así y la conseguiréis antes de cien años».

12 Egin 28-2-96 (13). Ver, también, El Mundo del País Vasco 282-96 (3). También Arzalluz manifestó que el autogobierno «es un derecho humano al que nadie puede poner coto» y que el nacionalismo consistía en «querer ser un pueblo» y «gobernarnos a nosotros mismos sin invadir a nadie». Tales afirmaciones acompañaban a otras que destacaban la difuminación de los atributos convencionales del Estado dentro de la Unión Europea (Deia 29-2-96 (3).

13 El Mundo del País Vasco 29-2-96 (15 y 16). 
concepción nacional, donde tiene que haber una ley para todos»14-, por no haber culminado el Estatuto de Gernika y como éxito político del PNV frente a los radicalismos nacionalistas ${ }^{15}$. No obstante, se defendió la culminación del Estatuto, en primer lugar, y, después, el desarrollo de la primera disposición adicional de la Constitución, «en virtud de la cual nuestros títulos competenciales se pueden incrementar a través de la actualización de los derechos históricos» ${ }^{16}$.

El desarrollo del Estatuto exigía que la transferencia de las competencias pendientes se hiciese sin "prórrogas ni dilaciones» ${ }^{17}$. Pero, a pesar de que la autonomía no estaba cumplida íntegramente, Ardanza pudo llamar a los jóvenes del PNV «hijos ya de esta Euskadi autogobernada en democracia» y además, afirmar que «hacía siglos que Euskadi no gozaba de tanto autogobierno» ${ }^{18}$. Arzalluz defendió la necesidad de luchar por mantener lo conseguido en materia autonómica y en ese sentido manifestó que «más vale un pueblo despierto que un gran estatuto» ${ }^{19}$. Pero categóricamente afirmó que el Estatuto era un «marco de referencia» y que era útil ${ }^{20}$.

14 Deia 29-2-96 (3). Eran palabras de Arzalluz, quien añadió que no tenían «más importancia que la de ver cómo nos va a ir con esta gente». Ver también en Deia 29-2-96 (5) y Egin 29-2-96 (12) intervención de Anasagasti. Ver así mismo El Mundo del País Vasco 29-2-96 (12) y El País 29-2-96 (16 y 18).

15 Ver Deia 17-2-96 (7); Deia 23-2-96 (6); Deia 23-2-96 (8); El Mundo del País Vasco 29-2-96 (29), donde Arzalluz explicaba la falta de desarrollo del Estatuto Vasco de la siguiente manera: «Tanto el PSOE como el PP donde menos fuerza tienen es aquí y, por el contrario, gobiernan en casi todo el resto de autonomías. Es allí donde deben responder de lo que han llamado el "agravio comparativo". Este es uno de los mayores obstáculos para que haya un desarrollo estatutario pleno. Este es un tema que, o asumen todos que tiene que haber fórmulas y estatutos diferentes, o al Gobierno le va a crear quebraderos de cabeza»; El Correo 29-2-96 (24), donde, ante las acusaciones de Javier Arenas de discriminación en materia tributaria entre las Haciendas vascas y Navarra y el resto de las Comunidades Autónomas, Anasagasti echaba en cara al Partido Popular no haberle desmentido, lo que revelaba en su opinión «la falta de convicción del Partido Popular» sobre la materia. Anasagasti exigía a los conservadores vascos que reivindicasen la validez del Concierto Económico, «que es el nervio y la sangre del autogobierno de Euskadi».

16 Deia 23-2-96 (8).

17 El Correo 23-2-96 (27). Deia 25-2-96 (4): Exigencia de cumplimiento del Estatuto, Ley Orgánica.

18 El Correo 2-3-96 (21).

19 Deia 18-2-96 (6).

20 Esta afirmación se hizo en una entrevista de El Mundo del País Vasco 29-2-96 (16): «P.-El portavoz del EBB, Joseba Egibar, ha dicho recientemente que el Estatuto ha dejado de ser marco de referencia. R.- ¿Eso ha dicho Egibar? ¿Qué te apuestas a que se lo digo a Egibar y me contesta que eso no lo ha dicho él? El Estatuto es un marco de referencia y claro que sirve. A todo el que dice lo contrario yo le respondo: no puedes conseguir que cumplan el Estatuto y qué coño vas a renegociar. Si no tienes fuerza para que te apliquen lo que hay, de qué vas a tener tú fuerza para que te den más». 
Este planteamiento constitucional de la autonomía vasca era interpretado como un proceso abierto, cuya legitimidad nacía del antiguo Régimen Foral y cuyos límites lo determinarían la voluntad de los vascos y las exigencias de la construcción de la Unión Europea. Así lo expresó Olabarría: «El Estatuto obtiene su legitimidad de nuestros antiguos regímenes forales y es una Constitución para Euskadi, por cuanto establece las competencias en las que los vascos nos autogobernamos. El Estatuto es abierto y dinámico, porque la actualización de los derechos históricos a futuro (sic) no se puede evaluar. Los derechos que en virtud de nuestra historia nos puedan corresponder son aquellos derechos que si el régimen de nuestra foralidad no hubiese sido interrumpido hubiesen continuado profundizando en los niveles de soberanía. Eso nos debe llevar hasta donde la voluntad de los vascos quiera el día de mañana sin más limitaciones que las que se deriven de la construcción de Europa y de las competencias que se tengan que ceder a la $\mathrm{UE} »^{21}$.

En esta perspectiva el nacionalismo del PNV rechazaba el Estado Federal. «El planteamiento de un estado federal - manifestó Gangoiti a Deia - yo lo he definido siempre como el gran planteamiento centralista de las personas inteligentes. Mientras que desde sectores tradicionales de la derecha española se ha hablado de un centralismo puro y duro, otros sectores han hablado de federalismo. Y un Estado federal, aunque le pongan ese nombre y suene muy bien, es la LOAPA. Nosotros defendemos el hecho diferencial vasco y nos apoyamos en la tradición histórica de este país, en la voluntad de este pueblo, pero también en el artículo dos de la Constitución, que habla de nacionalidades, y en las disposiciones adicionales de ésta y el Estatuto, sobre derechos históricos del pueblo vasco... Me llama la atención que desde el nacionalismo español se recurra a un planteamiento federal, cuando es un planteamiento que viene de fuera, y en la historia del propio Estado español hay un sistema que funcionó, que es el del pacto con la Corona, que trasladado a los modelos actuales sería una confederación de la nación vasca con el Estado español, es decir, con las naciones que lo forman para crear un Estado multinacional» ${ }^{22}$.

Se utilizó alguna fórmula indeterminada en sustitución de la reclamación de independencia. Así se aludió a la autodependencia, de la que se habría disfrutado en otros tiempos, como objetivo de los vascos. Arzalluz manifestó en este sentido que «eso hemos hecho siempre y queremos

21 Deia 23-2-96 (8), entrevista a Emilio Olabarría.

22 Deia 1-3-92 (4), entrevista a Jon Gangoiti. En otra entrevista de Deia a Pello Caballero, éste, en oposición con otras manifestaciones, que consideraban al Senado como una institución inútil, defendió la utilidad y la funcionalidad del mismo Deia 24-2-96 (6). 
hacer los vascos: depender de nosotros mismos» ${ }^{23}$. Fue Egibar, quien con carácter excepcional, además de confuso, defendió la legitimidad de la aspiración a la soberanía y manifestó que «el PNV reclama la soberanía de tal manera que en cada momento podamos hacer frente a los retos, para que podamos pactar con otras realidades nacionales preservando nuestra identidad. Queremos que el pueblo vasco sea dueño de su presente y protagonista de su futuro. A lo que nos negamos es a ser partes descentralizadas de un todo» ${ }^{24}$.

A esta idea se añadía la afirmación de que todos los vascos formaban «un mismo pueblo» ${ }^{25}$ y de que el PNV, a diferencia de los Partidos de ámbito nacional, marcaba «exclusivamente el perfil de lo vasco» ${ }^{26}$.

El 4,82\% de la campaña del Partido Nacionalista (10,44\% de la imagen o identificación como Partido político) dedicado a contenidos o mensajes nacionalistas fue espacio suficiente para recordar el póquer de argumentos utilizados habitualmente por el PNV para reivindicar más poder político: la Constitución formal de 1978, el Estatuto de Gernika, la Constitución histórica, la nación, la autodeterminación, la historia, el pueblo, la voluntad popular o la identidad nacional.

Tal vez, podría añadirse a todo lo escrito sobre contenidos nacionalistas, la pretensión del PNV de presentarse a las elecciones conjuntamente con Eusko Alkartasuna. El fracaso de semejante intento lo comentó Anasagasti diciendo: «Hemos intentado ir juntos a las elecciones, aunque no ha habido ninguna posibilidad. Cuando llegó Xabier Albistur nos pareció que éramos como la Pepsi Cola y la Coca Cola. Ahora, como estamos juntos en el Gobierno vasco y en las diputaciones, nos pareció que era el momento de presentarnos conjuntamente, pero no quisieron ${ }^{27}$.

\section{Los contenidos o argumentos no nacionalistas}

De los temas abordados o mencionados en este apartado, sólo tres tuvieron relevancia electoral. El más tratado fue el de la paz y la violencia, que alcanzó el $37,12 \%$, lo que representa el $23,04 \%$ de la imagen de partido y el 10,63\% del total de la campaña.

Otro de los temas más manejados fue el de la definición abstracta o expresa de Partido, que alcanzó el 35,64\%, es decir, el 22,11\% de la imagen

23 El Correo 18-2-96 (38).

${ }^{24}$ Deia 23-2-96 (6). También aparecía, incidentalmente, en la entrevista de Deia a Emilio Olabarría.

25 El Correo 26-2-96 (20).

26 El Correo 27-2-96 (20).

27 El Correo 27-2-96 (21). 
y el $10 \%$ del total de la campaña. El tercero fue el de los éxitos alcanzados por la gestión del Partido Nacionalista, que llegó al 15,59\%, es decir, el $9 \%$ de la Imagen y el $4 \%$ del total de la campaña.

El resto de las cuestiones alcanzó el 11,63\% de este apartado, representando el $7,21 \%$ y $3 \%$ de la Imagen y de la campaña, respectivamente.

En relación a la cuestión de la paz y de la violencia, aunque la magnitud de los datos dados es matemáticamente correcta, cualitativamente hablando hay que reconocerle mayor importancia, ya que en buena medida la definición expresa de Partido se hizo en relación con el rechazo de la violencia y la defensa de la paz. También la crítica a los Partidos se centró en buena medida sobre las estrategias sobre la violencia.

La postura nacionalista sobre el terrorismo y la violencia, que exigía superar la pereza mental y política que impedía entender y comprender a los violentos ${ }^{28}$, destacaba diversos aspectos. En primer lugar, su condena ${ }^{29}$; en segundo lugar, la necesidad de un diálogo limitado con ETA o con su entorno social ${ }^{30}$, diálogo, del que no se debía excluir a nadie ${ }^{31}$, aunque no había por el momento condiciones para una negociación ${ }^{32}$; en tercer lugar, el imprescindible papel del PNV en la solución de la violencia, ya que era la única formación política que trabajaba por hacer converger las posturas de los radicales nacionalistas y la de los principales partidos políticos ${ }^{33}$; en cuarto lugar, el rechazo tanto del frentismo como del aislamiento en la estrategia antiterrorista ${ }^{34}$; en quinto lugar, la

28 Ver El Correo 24-2-96 (18).

29 Toda la campaña es una condena permanente de la violencia. Ver especialmente $E l$ Correo 18-2-96 (38), intervención de Arzalluz en el mitin de Anoeta. Ver, también, en El Correo 19-2-96 (20) las palabras de Anasagasti en el mitin de Arrigorriaga y El Correo 17-2-96 (24) y, en general, todos los textos de crítica hacia ETA y HB.

${ }^{30}$ Ver El Correo 18 y 19-2-96 (38 y 20 respectivamente). Según el cronista de la reunión política de Anoeta, la tesis de Arzalluz, también defendida en el mismo lugar por Egibar, sobre la compatibilidad de la condena del terrorismo con la defensa del diálogo con ETA fue lo más importante y sobresaliente que se dijo; ver El Correo 18-2-96 (38). En El Correo 28-2-96 (23) Ollora manifiesta que tras las elecciones habrá que «hablar de un final dialogado y de distensión». La solución dialogada se recogía en el programa electoral; era una fórmula que favorecería la integración social de los «sujetos activos y pasivos» (Ver El Correo 16-2-96 (25). Ver, también, Deia 16-2-96 (10); El Mundo del País Vasco 29-2-96 (14-16): diálogo según el Pacto de Ajuria Enea; opinión de Arzalluz, que califica de difícil, pero de mayor utilidad que la aparente, el diálogo con ETA, y que duda de que ETA quiera acabar con el conflicto.

31 Ver El Correo 24-2-96 (18).

32 Ver El Mundo del País Vasco 29-2-96 (14).

33 El Correo 23-2-96, (27); intervención de Egibar en San Sebastián. Ver también en El Correo 28-2-96 (23) el criterio de Juan María Ollora.

34 El Correo 28-2-96 (23); Ollora en el mitin de Oyón. 
conveniencia para el diálogo de la «intimidad política» fuera del Parlamento Vasco ${ }^{35}$; en sexto lugar, el reconocimiento de que ETA era la respuesta a la violencia del franquismo, a la ausencia de democracia y al terrorismo de Estado $^{36}$, afirmación que Egibar hacía extensiva, aunque sin concretar, al año 1996, al decir que era necesario «buscar fórmulas para dar salida a una serie de aspectos políticos que están haciendo que determinada gente mate» ${ }^{37}$; en último término, una solución que sustituyese el sufrimiento de la violencia, que hacía perder a todos, especialmente al nacionalismo, por una situación en que todos saliesen ganando $\operatorname{alg} 0^{38}$.

Estas tesis sobre la violencia se hacían compatibilizar con una interpretación del Pacto de Ajuria Enea, que Arzalluz resumió de la siguiente manera: «No es un pacto de persecución, sino un acuerdo en el que todos los que nos decimos demócratas ofrecemos un cuadro de actuación a los que van por su cuenta utilizando la pistola y la bomba para conseguir la independencia de Euskadi o la revolución». La Mesa de Ajuria Enea, añadía, «rechaza la violencia como método de alcanzar fines políticos, pero ofrece a los violentos las puertas abiertas para incorporarse a la democracia y, en el plano individual, la reinserción» ${ }^{39}$. El

\footnotetext{
35 Ver El Correo 24-2-96 (18).

36 Ver El Correo 16-2-96 (25), que resume parte del Programa.

37 El Correo 24-2-96 (18).

38 Ver El Correo 24-2-96 (18).
}

39 El Correo 18-2-96 (38). En El Mundo del País Vasco 29-2-96 (14 y 15) se puede leer sobre la negociación, el diálogo y el final de la violencia esta conversación entre el entrevistador y Arzalluz: «P.—¿Qué se puede negociar con ETA? ¿Se puede dar una negociación política con los terroristas?- R.-Nosotros no tenemos asumido hoy por hoy que con ETA pueda haber una negociación política. ¿Qué entendemos por negociación política? Pues, por ejemplo, que a partir de una mesa como la de Ajuria Enea decidamos que, en pro de la unidad vasca, Navarra forme parte de la comunidad. Eso no podremos hacerlo nunca. ¿Por qué?, porque eso depende de la gente de Navarra y nosotros no podemos suplantarla en ese sentido. Hablar se puede hablar de todo, el problema son las condiciones que imponen ellos. Si se habla del reconocimiento del derecho de autodeterminación, los partidos como nosotros siempre estaremos de acuerdo. Si se va a abordar el tema de los presos, entonces los partidos podemos mostrar cuál es nuestra voluntad. ¿Pero hasta qué punto la Mesa de Ajuria Enea puede decidir que los presos salgan y en qué condiciones cuando existe un Poder Judicial por medio?P. - ¿Se verá a los partidos sentados con ETA en una mesa cuando llegue el final de la violencia?- R.- Claro, ese es el Pacto de Ajuria Enea. Cuando ETA manifieste una voluntad inequívoca de abandonar las armas entonces se iniciará el proceso de diálogo limitado por lo que ya hemos definido por concesiones políticas.- P. - ¿No podría llegar el final de la violencia por vías distintas a la del Pacto?-R.- Puede ser. Y desde luego las vías de solución no son solamente éstas, aunque los esquemas suelen ser más o menos parecidos. El Pacto de Ajuria Enea comenzó a raíz de una entrevista entre González y Miterrand. Este, que había sido dos veces ministro del Interior francés, le dijo a González que se metiera bien una cosa en la cabeza: que estas cosas no acaban sólo con la fuerza. Yo creo que un fenómeno como 
Pacto, pues, sería cumplido por el Partido Nacionalista en el proceso de pacificación ${ }^{40}$, aunque se dudaba de que los demás miembros del Pacto de Ajuria Enea fuesen capaces de ponerse de acuerdo sobre la estrategia antiterrorista $^{41}$.

Varios aspectos más completaban la visión de la violencia del nacionalismo. Destacaba una medida a largo plazo, que era la educación para la paz. Era tarea de los docentes — dijo Ardanza — «desenmascarar esa "pedagogía social" que hace la violencia» ${ }^{42}$; los jóvenes debían ser educados en los valores pacifistas; había que inculcarles «un compromiso con la humanidad», que permitiese aflorar los sentimientos de «conmoción» ante los hechos violentos ${ }^{43}$. El mismo Ardanza dijo a los jóvenes en el mitin final de la campaña: «Comenzad ya a tomarnos el relevo en esta tarea. No dejéis este asunto sólo en nuestras manos. Porque vosotros, hijos ya de esta Euskadi autogobernada en democracia, tenéis que

éste puede acabar incluso por agotamiento, pero no pienso que pueda morir por una acción policial, o al menos que pueda quedar muy amortiguado. ETA no es el GRAPO, al que no le respalda nada sólido socialmente. Si hoy ETA sólo fueran comandos, el planteamiento sería otro.- P.— ¿Y no podría llegar el final del terrorismo por los propios errores de ETA?R.-También, claro. Y creo que los están cometiendo. Pienso que, concretamente estas últimas muertes, les han salvado las elecciones, pero no creo que les beneficie en nada incluso en su propio mundo. Veo que cada vez hay una mayor redicalización. Todo ese intento de KAS de agarrar el movimiento es porque se les cae por los michelines, por decirlo de alguna manera. Han visto que han perdido 70.000 votos en no mucho tiempo y se hablaba que en las próximas elecciones podrían perder otros 30.000 , aunque esa cifra me parece un poco exagerada. El propio debate de si se presentaban o no a las elecciones es significativo. En definitiva, su solución es controlar, y controlar su propia disidencia. Pretenden que cuando llega la negociación, y ellos dicen que vendrá cuando lo quieran, no haya voces discordantes. La verdad es que la negociación no se abordará cuando ellos quieran. En eso están equivocándose seriamente.- P.— ¿Ha influido algún factor para que el PNV se decidiera a explorar por su cuenta alternativas distintas al Pacto en la búsqueda de la paz? - R.- Ha habido un factor, tal vez coyuntural pero muy importante, que ha sido el de los procesos irlandés y palestino. Se puede decir que han sido milagrosos porque hasta hace muy poco estaban a balazo limpio. Nosotros hemos estado en Jerusalem y nos han contado cosas que nos han impresionado, porque el diálogo no se inició por iniciativas del Gobierno israelí y ni siquiera de Arafat, sino por iniciativas privadas, de movimientos sociales. El origen del proceso nos impresionó mucho, por eso comenzamos a trabajar con movimientos como Elkarri o Gesto por la Paz y designamos a personas que fueran por ese camino. Con gran escándalo de algunos, por cierto, pero sin más pretensión por nuestra parte. Ha sido un salto mortal, pero también el intento de facilitar con la experiencia que hemos visto a través de fenómenos incluso más duros del que pueda representar ETA en el Estado español». Sobre la negociación política ver, también, Deia 28-2-96 (3) y El Mundo del País Vasco 28-2-96 (7).

40 Ver El Correo 20-2-96 (14). Ver, también, El Mundo del País Vasco 20-2-96 (7); Deia 26-2-96 (4): validez del Pacto de Ajuria Enea.

41 Ver El Correo 29-2-96 (24).

42 El Correo 28-2-96 (23).

43 Ibidem. Ver, también, El Correo 24-2-96 (18) y Deia 28-2-96 (5). 
poneros desde ahora la meta de alcanzar para vuestros hijos e hijas una nueva Euskadi reconciliada y en paz» ${ }^{44}$.

El rechazo de la identificación del nacionalismo con la violencia, argumento más frecuentemente utilizado en las acusaciones a los demás Partidos, era una lógica consecuencia de todo lo anterior. Arzalluz manifestó en este sentido que «muchos nos confunden con ETA y nos quieren meter en el mismo saco», añadiendo que «aparte de las víctimas, nadie sufre más que los vascos y, sobre todo, los nacionalistas. Aunque nos difamen, nosotros seguiremos con nuestra razón. Rechazamos a cualquiera que nos mezcle con los violentos, porque nosotros también hemos sufrido la intolerancia» ${ }^{45}$. Palabras semejantes pronunció al final de la campaña al definir el doble papel de los nacionalistas: «frenar aquí a los violentos» y ser «factor moderador en Madrid donde nos acusan de ambigüedad y hasta confunden, en ocasiones, terrorismo con nacionalismo» ${ }^{46}$.

El Partido nacionalista se comprometía a pedir que en la próxima legislatura se esclareciese toda la guerra sucia contra el terrorismo desarrollada desde 1977, porque, en palabras de Anasagasti, «sobre la porquería no se puede construir nada ${ }^{47}$.

Arzalluz, que dudaba de que los integrantes del Pacto de Ajuria Enea se pusieran de acuerdo para luchar contra la violencia, pidió a sus militantes sensatez ante el problema, porque «es un fenómeno que desaparecerá» ${ }^{48}$.

El Partido Nacionalista Vasco era, por supuesto, pacífico, además de nacionalista y demócrata ${ }^{49}$, pero era, también, de ideología social cristiana.

44 El Correo 2-3-96 (21); mitin de La Casilla. Ver, también, El Correo 16-2-96 (25); Deia 29-2-96 (5).

45 El Correo 17-2-96 (24). Ver, también, El Correo 24-2-96 (18), Deia 16-2-96 (10). «La misma polarización de la campaña entre violentos y demócratas» iba interesadamente, según Anasagasti, en perjuicio de los partidos nacionalistas (Ver Deia 19-2-96 (3); Egin 19-2-96 (13) y El Mundo del País Vasco 19-2-96 (15). En Deia 25-2-96 (3): el nacionalismo no es violencia).

${ }^{46}$ El Correo 2-3-96 (21).

47 El Correo 24-2-96 (18).

48 El Correo 29-2-96 (24). En El Mundo del País Vasco 29-2-96 (15), Arzalluz manifiesta que las posibilidades de actuación de la violencia no podían ir aumentando. Se refería tanto a la violencia de ETA como a la de Jarrai, sobre la que dijo: «...Se atribuye la violencia juvenil a Jarrai y hay también una parte que no tiene nada que ver con ese movimiento. Están utilizando la marginación, incluso pagando. Hay una financiación importante en determinadas actuaciones. Yo creo que en cuanto la propia Policía vaya despejando cómo y dónde se produce eso les va a ser más difícil tener profesionalizada la algarada y el cóctel molotov».

49 Ver, además de todo lo ya indicado, El Correo 27-2-96 (22) y 28-2-96 (23). Así mismo, ver El Correo 20-2-96 (14), donde se dice que el PNV «durante una sublevación militar, defendió la legitimidad de una República con la que tuvo muchos problemas», destacando con ello la opción democrática nacionalista. 
Preguntado Anasagasti sobre si era el principal abanderado de la ideología democristiana del PNV, respondió: «Más que de la democracia cristiana, a mí me gusta hablar de ideología social-cristiana, que no tiene nada que ver ni con el egoísmo individualista ni con la planificación deshumanizada de ciertos socialismos. Y como últimamente se estaba oyendo hablar bastante en clave de odio, por eso he defendido que el PNV, aunque no es partido confesional, tiene detrás una amplia base cristiana en la que encajan mejor la tolerancia y el respeto que el odio. A mi madre le raparon la cabeza en Zarautz durante la guerra y, cuando llegó al otro lado de la frontera, su padre, mi abuelo, le dijo: "No odies nunca"» ${ }^{50}$.

La visión social nacionalista rechazaba la sociedad opulenta y defendía, por el contrario, la sociedad trabajadora, capaz de vivir de sus propios recursos y de «atender a los más necesitados y a sus disminuidos» ${ }^{51}$. No se defendía una concepción liberal de la sociedad, sino «solidaria y humanista ${ }^{52}$. Las prioridades se centraban, así, en la creación de riqueza, la formación de los ciudadanos y en la dedicación a los menos favorecidos, que era lo que medía la calidad de una sociedad ${ }^{53}$.

Arzalluz antepuso la justicia social a la independencia y criticó el modelo económico neoliberal y la benevolencia social con el delito fiscal ${ }^{54}$.

50 El Correo 27-2-96 (21). Ver, también, El Correo 20-2-96 (14) donde se atribuye a Arzalluz decir que no «perdona» a Aznar poner en duda el carácter democrático del PNV.

51 El Correo 27-2-96 (22); palabras de Arzalluz. Ver también El País 16-2-96 (21), Egin 16-2-96 (1) y Deia 16-2-96 (10).

52 Deia 16-2-96 (10).

53 El Correo 27-2-96 (22). Arzalluz manifestó en relación con el Estado de Bienestar que «nuestro nivel de estudios está por encima de diez estados europeos y por encima de la media europea;... tenemos la mejor asistencia sanitaria, la mejor asistencia a disminuidos, a drogadictos, la mayor cooperación al desarrollo, el salario social, y no aceptamos recortes en lo necesario» (Deia 16-2-96 (10)). Ver también Deia 28-2-96 (3), donde se califican de esenciales al nacionalismo vasco la defensa del Estado de Bienestar y una política industrial seria. Ver, asimismo, Egin 28-2-96 (13). Ante las críticas de ELA-STV al Gobierno Vasco por su carencia de política industrial, Arzalluz manifestó: «...Yo quisiera saber qué política industrial plantea ese sindicato, porque hasta ahora se callan como zorros» (El Mundo del País Vasco 29-2-96 (16)).

54 Ver Deia 27-2-96 (4), donde el encabezamiento de la información, recogida arriba en el texto y entrecomillada por el propio Deia, no parece coincidir con lo que a continuación se afirma: «El presidente del PNV argumentó que no quería una "patria de hambre" y que en su escala de prioridades en el objetivo último de que "los vascos nos gobernemos a nosotros mismos", primero hay que garantizar "la dignidad, es decir, una sociedad provisora que permita la materialización de la justicia social"». En El Mundo del País Vasco 29-2-96 (16) Arzalluz sale en defensa del Gobierno Vasco por su inversión en la reactivación industrial y añade: «En mi opinión, lo que sucede es que estamos en un nivel de vida demasiado alto para la generalidad. Ese nivel debe bajar y repartirse más, sobre todo en el empleo. No veo en muchos años otra fórmula factible. Aquí, como no bajemos todos un $10 \%$ en nuestros ingresos y con ese $10 \%$ se cree empleo, no hay otra fórmula». Ver Deia 23-2-96 (8). 
Por su parte, Jon Zabalía defendió un modelo público de previsión social complementado con un sistema privado de capitalización, además del Banco Público Vasco y la rebaja del Impuesto de Sociedades ${ }^{55}$.

Se pretendía ser el centro entre los «extremismos» del MLNV y el Estado centralista a favor de un país del que se consideraba al PNV su «eje vertebrador» y a sus candidatos los instrumentos de las instituciones vascas para defender los intereses vascos ante la Administración central ${ }^{56}$. La opción de centro explicaría los ataques por la derecha y por la izquierda y con ello el «buen camino» del PNV, que era, en palabras de Anasagasti, «el del respeto a las ideas ajenas, a la vida humana y el de entender que en democracia gobiernan las mayorías pero con escrupuloso respeto de las minorías ${ }^{57}$.

La idea de centro la defendió también Anasagasti en contraposición al Partido Popular. Este no sólo carecía de orígenes democráticos, sino que representaba «el regreso de la derecha de siempre». El PNV, por el contrario, encarnaba la «centralidad política» ${ }^{58}$. Y en la lucha con el Partido Popular por el voto el mismo político manifestó: «Nos disputamos el antiguo voto de UCD-CDS y ellos pretenden tomar la antorcha vasca. Pero, a nuestro juicio, aquí el PP no tiene estructura de partido político, funciona más como un club de fans. Es una cáscara vacía. Nos disputamos el centro electoral, porque en la derecha no creo que nosotros consigamos demasiados apoyos» ${ }^{59}$.

Si bien Ardanza no lo calificó como Partido de centro, sí lo calificó como la tercera opción, que se ofrecía en el País Vasco, superando la bipolarización PP-PSOE propia de otras comunidades. El PNV, con su «saber hacer», ofrecía «al país y a todos sus agentes económicos y sociales un horizonte de seguridad y de estabilidad para cuatro años» ${ }^{60}$.

Casi en la misma línea, Anasagasti defendía que en Madrid el PNV no era más que «grupo vasco» para la utilidad de Euskadi. El apoyo al PNV era «el único voto útil en Euskadi — argumentó- porque en Madrid somos grupo vasco y no del PNV, aunque con la filosofía de nuestro

55 Ver Deia 21-2-96 (4), donde se considera correcto el mapa bancario del momento y se dice de las Cajas que tienen que aportar mucho más en apoyo de las PYMES. Ver, asimismo, Deia 21-2-96 (6), 23-2-96 (8).

56 El Correo 28-2-96 (23). La centralidad, que aquí se especifica entre el MLNV y el Estado centralista, en otras ocasiones se establece entre la «derecha cerril» y la «izquierda radical seudoabertzale» (El Correo 1-3-96 (24)) o la minoría «fanática de la ultraderecha» y las «juventudes fanatizadas de Jarrai» (El Correo 19-2-96 (20)).

57 El Correo 19-2-96 (20) y demás lugares citados sobre el carácter centrista del PNV.

58 El Correo 19-2-96 (20). Ver Deia 24 y 28-2-96 (4 y 4).

59 El Correo 27-2-96 (20) y Deia 26-2-96 (4).

60 El Correo 26-2-96 (20). 
partido» ${ }^{61}$. Como por otra parte, se esperaba que ningún partido obtendría la mayoría absoluta, el carácter de «voto útil» aumentaba, ya que «el concurso de cinco senadores y cinco diputados puede ser muy importante en ese gran océano institucional» ${ }^{62}$, El «grupo vasco», además, se definía por ser y por desear «seguir siendo el cartero de Navarra, la única voz libre y representativa», según Albistur ${ }^{63}$.

La identificación con lo vasco incluía la identificación con los intereses vascos, tal como se destacó para diferenciarse de los grandes Partidos. «Los partidos de ámbito estatal — se dijo- tienen otros intereses en qué pensar. Nosotros, en cambio, cuando, por ejemplo, se trata del Plan Director de Infraestructuras, nos quedamos solos en la defensa de la línea del metro por la margen izquierda, mientras el PP se abstiene y el PSOE e Izquierda Unida votan en contra, pero aprueban la línea para el ferrocarril metropolitano de Madrid. Entonces, claro, se nota que nosotros marcamos exclusivamente el perfil de lo vasco porque podemos hacer un trabajo específico en defensa del Estatuto, de la presencia vasca en Europa y en temas económicos» ${ }^{64}$.

En lo que se refiere a la eficacia del PNV, Anasagasti resaltaba que, «aunque sólo hayan trascendido los escándalos, en esta legislatura se han aprobado 176 leyes y a todas hemos presentado enmiendas. Es decir, creo que nuestros diputados se han ganado merecidamente una imagen de gente trabajadora y competente. Formamos un grupo que pone mucho "fuego" en la defensa de sus tesis, pero que al mismo tiempo sobresale como respetuoso y de buen talante» ${ }^{65}$. En este sentido hay que resaltar la idea de que el nacionalismo vasco del PNV representaba fuera

61 El Correo 19-2-96 (20). Ver Deia 19-2-96 (3); 20-2-96 (3); 21-2-96 (6); 23-2-96 (6); Egin 20-2-96 (14).

62 El Correo 19-2-96 (20). En esta misma línea hay que situar la deseada victoria electoral en Guipúzcoa (ver El Correo 29-2-96 (24)), donde Anasagasti dice: «Nuestra mayor aspiración es ser la fuerza más votada en este territorio». El negativo de este argumento lo ofrecía González Txabarri: «No permitir que HB sea la primera fuerza en nuestro territorio, porque es una vergüenza que los que sustentan a los terroristas nos precedan en las encuestas del Gobierno vasco» (El Correo 18-2-96 (38)). Ver Deia 22-2-96 (6).

${ }_{63}$ El Correo 25-2-96 (32).

${ }^{64}$ Entrevista a Anasagasti en El Correo 27-2-96 (20). Ver Deia 28-2-96 (4) y 1-3-96 (5). Aquí se sitúan también las peticiones de presencia de las instituciones vascas en las empresas públicas ubicadas en la margen izquierda (El Mundo del País Vasco 21-2-96 (13). En otra entrevista Arzalluz manifestó que incluso la forma «confederal» de estructuración de la Comunidad Autónoma Vasca obedecía a la pretensión de «dar prioridad a la integración del País, aunque fuera en contra de nuestros propios intereses. Todavía hoy nos convendría cambiar el sistema atendiendo a nuestra representación. Es un clásico ejemplo de lo que nadie hace: ir en contra de sus intereses» (El Mundo del País Vasco 29-2-96 (16)).

${ }^{65}$ El Correo 27-2-96 (20). 
de Euskadi y, especialmente, ante el Estado lo vasco y los intereses vascos, que anteriormente se ha destacado ${ }^{66}$.

Y, por lo que se refería a La Comunidad Autónoma Vasca, Ardanza destacó que el Gobierno de coalición había obedecido a la pretensión nacionalista de que «funcionara como una cortina de seguridad, que librara a esta comunidad de la inestabilidad que se vivía en el Estado. Hoy, un año largo después, puedo decir que lo hemos conseguido» ${ }^{67}$. Este éxito ya lo había cantado al comienzo de la campaña el mismo Ardanza al comparar la situación institucional de Euskadi con la de otras comunidades autónomas. «Ahí tenéis Andalucía - dijo- - que ha sido incapaz de aprobar siquiera un presupuesto. Y ahí tenéis también a Extremadura, Asturias y hasta Cataluña, que tienen gobiernos en precario» ${ }^{68}$. Gracias al PNV el País Vasco ofrecía un «buen balance político y administrativo», que se dejaba ver, incluso, en la política industrial. Tal interpretación se enlazaba con un brindis a posibles pactos postelectorales, que no especificaban el candidato, porque éste saldría de las urnas. «Si alguien quiere compartir nuestro saber hacer — dijo Ardanza—, no vamos a tener complejos para contrastar programas y llegar a acuerdos» ${ }^{69}$.

En la defensa que Arzalluz hizo de la Ertzaintza y, sobre todo, en el rechazo de la acusación de que el PNV la patrimonializaba, también apareció el laborioso éxito nacionalista en conseguirla. La ocasión sirvió para defender a la policía vasca y denunciar, en cierto modo y una vez más, el enfretamiento entre lo vasco y lo español. «Ojalá — dijo Arzalluz- fuera (la Ertzaintza) patrimonio de todos. ¡El calvario que nos ha supuesto llegar a conseguir la policía que tenemos! Pero veréis cómo se van a meter con ella acusándola de incapacidad e incompetencia. Pero ¡ay de nosotros si nos atrevemos a criticar a cierta policía, sobre todo si es verde, porque no acaba de detener a ciertos comandos!»70.

66 Ver El Correo 19 y 25-2 96 (20 y 32 respectivamente). Ver, también, El Correo 23-2-96 (27), donde se habla del empeño del PNV por pedir la convocatoria de un pleno monográfico de política industrial.

67 El Correo 26-2-96 (20).

${ }^{68}$ El Correo 18-2-96 (38).

69 El Correo 18-2-96 (38). Emilio Olabarría destacó el, en su opinión, buen diseño de política industrial de Euskadi, cosa que no se veía en otros Partidos y, ni siquiera, lo había hecho el PSOE en el poder (Deia 20-2-96 (3)). Ver Deia 27-2-96 (3). En la buena gestión del Gobierno vasco se asentaría la supuesta voluntad mayoritaria de los vascos de que las pensiones y la Seguridad Social pasaran a la CAV. (Deia 17-2-96 (7)).

70 El Correo 18-2-96 (38). En Deia 18-2-96 (6) se añade: «Habrá otros que quieran meter aquí a la Guardia Civil para controlar todo, como lo hicieron en el día que se instaló en nuestros pueblos. También habrá quien, como ETA quiera que haya sólo una Guardia Municipal y, ojo, que no se meta con ellos». En Deia 25-2-96 (4) se leen declaraciones de que la Guardia Civil y Policía Nacional estaban envalentonados y que había que serenar la situación. En defensa de la Ertzaintza ver: Deia 24-2-96 (4) y El Mundo del País Vasco 29-2-96 (14-16). 


\section{Estrategia o Política postelectoral. Los posibles pactos de gobierno}

Ya se ha indicado en la aportación de los datos generales de la campaña del PNV que la crítica al Partido Popular ocupó buena parte de aquélla. Esto fue así principalmente durante los diez primeros días, en los que ya se había expresado la voluntad del PNV de estar dispuesto sin complejos a compartir su capacidad de gobierno con otros, previo establecimiento de programas y de acuerdos ${ }^{71}$. Se estaba abierto a cualquier Partido. El candidato o candidatos los tenían que resolver las urnas y los programas, pero, de momento, lo resolvieron las encuestas electorales.

Después de una extensa crítica contra el Partido Popular, la derecha española y los políticos conservadores, cuyo corolario había sido insistir en la dificultad, si no imposibilidad, de un entendimiento con el Partido Popular o, tal vez, de meras conversaciones postelectorales $^{72}$, Arzalluz defendió la necesidad del pacto en política por razones de gobierno y de estabilidad política. Y lo hizo con un ejemplo, que, por cierto, destacaba más el interés particular que el interés general, que aparentemente trataba de defender. «Al final — dijo- tienes que llegar a un acuerdo con la vecina del segundo porque, si no, tienes que subir andando hasta el sexto piso con las bolsas de la compra. Y en política pasa lo mismo porque, al final, lo que interesa es gobernar y favorecer la estabilidad» ${ }^{73}$. Esto se dijo en un contexto en que no se especificaba con qué partido se estaba dispuesto a pactar. Más bien el orador había mostrado un distanciamiento claro, tanto con el Partido Socialista como con el Partido Popular. Se establecía, pues, un principio general, que al no excluir expresamente al Partido de Aznar, lo incluía como candidato.

Establecido el principio general y la disponibilidad del PNV a aplicarlo por razones no partidistas, sino de bien general, se comenzó a hablar de las posibilidades de pactar con el Partido Popular. Las manifestaciones de los políticos nacionalistas, especialmente las del final de la campaña, daban por supuesto que el PP tendría que llamar después de las elecciones a la puerta del PNV y de los demás Partidos nacionalistas en busca de apoyos al Gobierno de Aznar ${ }^{74}$. Arzalluz pronosticó al Partido Popular «10 o 15 escaños por debajo de la mayoría absoluta»,

71 El Correo 18-2-96 (38), ya citado anteriormente.

72 El Correo 20-2-96 (14): Manifestaciones de Arzalluz. Ver El Mundo del País Vasco 20-2-96 (7).

73 El Correo 26-2-96 (20).

74 Ver: El Correo 23-2-96 (27); 29-2-96 (24); 2-3-96 (21). 
lo que haría obligatorio el pacto con otros grupos políticos ${ }^{75}$. En principio, el PNV no se sentía atraído por el discurso electoral del Partido Popular. Más bien estaba predispuesto en contra de un posible pacto, ya que Aznar utilizaba un lenguaje duro e insultante hacia los nacionalistas vascos, buscando con ello un buen resultado electoral. Entre otras cosas, se reprochaba a Aznar haber dicho que primero hay que ser demócratas y después nacionalistas ${ }^{76}$. El Partido Popular estaría buscando, en la interpretación, que hacía Anasagasti, la mayoría absoluta, para lo que utilizaba un lenguaje antinacionalista, consciente de que si únicamente lograba la mayoría simple, contaría con el apoyo de un PNV, siempre defensor y, de hecho, acostumbrado a políticas pactistas. El portavoz nacionalista en el Congreso destacaba que, una vez llegado este momento, un posible pacto exigiría, en primer lugar, la satisfacción de los intereses del PNV, porque «los hombres y los rocines cada uno va por sus fines»y, en segundo lugar, el mantenimiento del carácter nacionalista del PNV, ya que éste jamás aceptaría la pretensión Popular de su conversión en un mero Partido autonomista. «El "abc" de nuestro ideario no lo vamos a vender por un plato de lentejas», sentenció Anasagasti ${ }^{77}$.

El posible pacto con el Partido Popular exigía que éste hiciese un esfuerzo de acercamiento, porque, en definitiva, «a un Gobierno del PP no le interesa tener al PNV en las trincheras, porque nosotros en la oposición somos muy duros» ${ }^{78}$. Por otra parte, la posibilidad de hacer la «pinza»

75 El Correo 29-2-96 (24). Semejante afirmación aparece en El Correo 2-3-96 (21). Ver, también, El Correo 27-2-96 (20) y 28-2-96 (23), donde se habla de posibles resultados electorales de los populares, que harían necesaria la colaboración política.

76 Otras quejas contra el Partido Popular las expresaba Anasagasti con estas palabras: «En primer lugar no se puede poner un "tirapiedras" para que nos acuse de cerrar la "comisión GAL" y de otras maldades. En segundo lugar, nosotros siempre hemos recelado de la derecha, que nunca ha intentado que los nacionalistas olvidemos el pasado» (El Correo 27-2-96 (20)). En El Correo 23-2-96 (27) Anasagasti informa que el PNV estaba elaborando un dossier con todos los insultos dirigidos por el PP contra el Partido Nacionalista.

77 El Correo 27-2-96 (20); entrevista a Iñaki Anasagasti, en la que éste responde a la pregunta del periodista de si «Entiende y acepta que el PP pretenda conseguir del PNV, ante todo, un compromiso con el proyecto democrático de España» de la siguiente manera: «Ese es un planteamiento de bisoños, pero no de personas serias y maduras. Porque a la gente hay que tomarla tal y como es, no como uno quisiera que fuera. A mí, en cierta ocasión, Rodrigo Rato me dijo que el PP perseguía la victoria por mayoría absoluta pero, en caso contrario, «ya pactaréis con nosotros porque a vosotros os van los pactos». Creo que se equivoca. Para que eso fuera así, el Partido Popular tendría que tender muchos puentes y no es lo que está haciendo. Al contrario, utiliza un discurso muy duro, que le da votos, pero no soluciona nada. Felipe González nunca nos ha insultado. En cambio, Aznar sí. Y eso nos predispone en contra. Además, «los hombres y los rocines cada uno va por sus fines». Podemos llegar a un pacto, pero no al que ellos quieran. Desde luego, el PP se equivoca si sueña con intentar convertirnos de partido nacionalista en autonomista. El "abc" de nuestro ideario no lo vamos a vender por un plato de lentejas».

78 Ibidem. 
a un Partido Popular débil entre los partidos nacionalistas y el PSOE era posible, pero no deseable, «porque a nosotros nos interesan legislaturas que se cumplan hasta el final con estabilidad política. La inestabilidad de estos dos años ha sido nefasta, incluso para la lucha contra el terrorismo. Pero, en todo caso, estamos dando por hecho que va a ganar el PP y yo no lo tengo tan claro» ${ }^{79}$.

Según esto, había razones e intereses generales y particulares para la colaboración entre los dos Partidos —incluso en determinadas políticas, como la de aplicación del Pacto de Ajuria Enea, la colaboración del PNV era imprescindible-, pero correspondía al Partido Popular hacerla posible. Por ello se le exigía un esfuerzo especial de aproximación y se le advertía, además, de que su victoria electoral no era segura y de que había menos trabas para entenderse con el Partido Socialista ${ }^{80}$.

La posible colaboración postelectoral se hizo tema habitual en los últimos días de campaña. El Partido Nacionalista insistió en que él no estaba ni con uno ni con otro, es decir, ni con el Partido Socialista ni con el Partido Popular. «Nosotros no somos amigos ni del PSOE ni del PP» ${ }^{81}$, dijo Arzalluz, que se despidió de los mítines afirmando su distanciamiento tanto del «que se va como del que viene» ${ }^{82}$. Pero, al estar los políticos nacionalistas convencidos de que el PP no obtendría la mayoría absoluta $y$, por consiguiente, la colaboración con otros Partidos sería imprescindible, se consideraba que correspondía a los populares buscar la colaboración y el apoyo político ${ }^{83}$.

Sin embargo, el Partido de Aznar estaba aplicando en la campaña la misma estrategia de acoso y desacreditación de los contrarios, que había seguido durante la legislatura anterior ${ }^{84}$. No había muestras de buscar el consenso político con los nacionalistas, sino más bien todo lo contrario, como lo demostraban los ataques de Javier Arenas al sistema seguido por las Haciendas de las Diputaciones vascas por considerarlo una discriminación. Por otra parte, Arzalluz recordaba el último día de campaña que el «primer apaleado por la derecha española ha sido siempre el vasco»y,

79 Ibidem. En Deia 25-2-96 (4) se dice que la estabilidad política había que buscarla con quien fuese.

80 El Correo 27-2-96 (20).

81 El Correo 2-3-96 (21); palabras de Arzalluz.

82 Ibidem.

83 Ver El Correo 28-2-96 (23), donde Arzalluz afirma que «sin nosotros y Pujol» previsiblemente no podrán los populares aprobar los Presupuestos y se informa del ofrecimiento de colaboración de Aznar a los nacionalistas catalanes.

${ }^{84}$ Ver El Correo 29-2-96 (24), donde Arzalluz dice que «éste es un tiempo de consenso en España, pero el Partido Popular ha ido siempre al derribo, a desacreditar y tumbar a sus rivales».Ver Deia 25-2-96 (3): La política de arrogancia y aislamiento del PP dificultará la formación de Gobierno. 
también, que entre los simpatizantes del Partido Popular se encontraban quienes estarían dispuestos a implantar un régimen totalitario ${ }^{85}$. Por todo ello, las relaciones entre PNV y PP estaban tan deterioradas que se dudaba seriamente de que los diputados nacionalistas pudieran dar su apoyo a Aznar en el Congreso. En aquel momento los nacionalistas se encontraban situados en el mismo bando que el PSOE e IU ${ }^{86}$. Pero, a pesar de todo, el acuerdo con los populares no era imposible, palabra que no existía en el vocabulario nacionalista, según Anasagasti; el PNV no cerraba «las puertas» a un entendimiento con el Partido Popular ${ }^{87}$. En el supuesto de que ganase, el PNV no se iba a «escaquear — según palabras de Arzalluz- diciendo que son unos fachas. Si nos llaman, hablaremos, porque a todos nos interesa que haya un Gobierno fuerte» ${ }^{88}$.

La colaboración, que de ninguna manera se especificó en su forma, dependía de varios factores; en primer lugar, de la voluntad política del PP; en segundo lugar, de que Aznar pudiese dominar a todos (banqueros, caciques y patronos) los que pretendían volver a la situación anterior a la democracia ${ }^{89}$; en tercer lugar, del ofrecimiento de objetivos y políticas aceptables para una acción de gobierno ${ }^{90}$, que, en cualquier caso, debía despejar las dudas o incógnitas que en materia estatutaria, pacificación y Concierto Económico presentaba el programa del PP; por último, de que fuera conveniente no sólo para el Partido Nacionalista, sino también para las demás fuerzas y grupos políticos. El apoyo sería leal y sin ningún tipo de chantaje. Pero, en el supuesto de que no se diesen semejantes condiciones, el Partido Nacionalista se iría a la oposición ${ }^{91}$. Ahora bien,

85 El Correo 2-3-96 (21). Ver El Mundo del País Vasco 2-3-96 (10). En otra ocasión Arzalluz había manifestado: «Nuestra experiencia con la izquierda ha sido mala, pero con la derecha... ha sido tremenda» (Deia 26-2-96 (3)).

86 Ver El Correo 29-2-96 (24).

87 El Correo 29-2-96 (24).

88 El Correo 2-3-96 (21). Hablando Arzalluz en El Correo 28-2-96 (23), también, sobre la posibilidad de colaborar con el PP, puso estas condiciones: «Mirar si (Aznar) puede dominar la situación y segundo ver qué piensa hacer y si lo que piensa hacer es sensato y pensamos que nos conviene, no sólo a nosotros, no vamos a andar diciendo que éste es un "facha", sino que le apoyaremos, pero si hace lo contrario nos opondremos».

89 En El País 27-2-96 (20) Anasagasti incluye al Obispo Elías Yanes entre los poderes fácticos, que apoyaban al PP. («P.-Dibujan ustedes al PP como un cúmulo de intereses... R.-Y un cúmulo de apoyos declarados, como los banqueros tipo Botín, los empresarios como Cuevas, sin olvidar al obispo Elías Yanes, un hombre muy exquisito cuando quiere, pero al final... Los poderes fácticos están apoyando a tope al PP»).

90 Aquí se incluían el Estado de Bienestar sin recortes, tal como ya se ha destacado (ver Deia 16-2-96 (10) y Egin 16-2-96 (3) y lugares citados anteriormente), y los objetivos de la Unión Europea, pacificación, autogobierno, política industrial, social y económica ya conocidos (ver El País 27-2-96 (20 y 21) y lugares citados).

91 Ver El Correo 28-2-96 (23) y 29-2-96 (24). 
supuestas las condiciones para pactar, el PNV no tendría complejos para hacerlo; no estaban «los tiempos para testimonialismos», declaró Ardan$\mathrm{za}^{92}$.

B) La crítica a los Partidos Políticos

\section{El Partido Popular}

No hubo un solo día de campaña, en el que los nacionalistas dejasen de atacar al Partido Popular, «autubús donde entra y sale gente en todas las paradas ${ }^{93}$. Así se entiende lo que se ha indicado más arriba: que el $62,31 \%$ de este apartado estuviese ocupado por el Partido de Aznar. Esto representa un 33,54\% del total de la campaña, lo que quiere decir que una de cada tres palabras se dijo contra los que, acogiendo a lo más descarado de la derecha española, en palabras de los mitineros nacionalistas, buscaban el voto de centro, disputándoselo al PNV.

Tres cuestiones acapararon prácticamente la ofensiva contra los conservadores populares: la denuncia de los ataques de éstos al PNV por nacionalista; la acusación de ultraconservadurismo y la falta de programa y de experiencia.

Aunque en algunos casos se incluía en la crítica nacionalista a otros grupos, tanto políticos como sociales, al Partido Popular se le condenaba por confundir al PNV con ETA y a la «violencia con el nacionalismo», aunque «aparte de las víctimas nadie sufre más que los vascos y, sobre todo, los nacionalistas. Aunque nos difamen, nosotros seguiremos con nuestra razón. Rechazamos a cualquiera que nos mezcle con los violentos porque nosotros también hemos sufrido la intolerancia» ${ }^{94}$.

Estas afirmaciones del comienzo de campaña se repetieron casi textualmente al final de la misma, cuando Arzalluz, al destacar el papel moderador del nacionalismo en Madrid, añadió que allí «nos acusan de ambigüedad y hasta confunden, en ocasiones, terrorismo con nacionalismo» ${ }^{95}$.

92 Deia 26-2-96 (3). Ver El País 29-2-96 (16) y El Mundo del País Vasco 29-2-96 (12): las posibilidades del pacto con el PP. Sobre el Partido Popular, en general, incluyendo críticas, acusaciones, condiciones y posibilidades de acuerdos de Gobierno, se puede consultar en los últimos días de campaña: Deia 28-2-96 (3) (condición del Pacto: el final dialogado de la violencia), 29-2-96 (5) y 1-3-96 (5); El País 27-2-96 (20 y 21) y 29-2-96 (16 y 18); Egin 29-2-96 (14) y 2-3-96 (14); El Mundo del País Vasco 29-2-96, 1-3-96 (13) y 2-3-96 (10). Con anterioridad se puede ver: Deia 22-2-96 (6) (condiciones para apoyar al PP); Deia 17-2-96 (7), El Mundo del País Vasco 24-2-95 (14) y Deia 25-2-96 (3) (el pacto con los populares: cuestión de programa); Deia 25-2-96 (6) (condiciones de un pacto de Legislatura).

93 Deia 25-2-96 (4).

94 Palabras de Arzalluz en El Correo 17-2-96 (24).

95 El Correo 2-3-96 (21). 
Los ataques al Partido Nacionalista se enmarcaban dentro de una estrategia ya habitual en los populares, que utilizaban el odio y la satanización del adversario político. Se pretendía el derribo y la desacreditación de los rivales, estrategia que contrastaba con el hecho, según Arzalluz, de que aquél era «un tiempo de consenso en España» ${ }^{96}$. En este sentido Anasagasti no dudaba en señalar al mismo obispo Setién como agredido por los populares. «Se presentan como cristianos — dijo- y no hay día en que no agredan verbalmente al Obispo Setién. ¿Por qué un cristiano tiene que agredir de forma continuada a un obispo? $\gg^{97}$. La pregunta, que ocultaba la lucha por el voto de centro y de los demócrata-cristianos, se respondía con la negación del carácter de democristiano al Partido Popular y daba ocasión para distinguir entre la oposición del PNV al nombramiento del obispo de Bilbao, Blázquez, calificada de «oposición técnica», y el propósito Popular de «deslegitimar» a Setién.

La campaña «sucia y muy negativa» del $\mathrm{PP}^{98}$ puso en duda la democracia de los nacionalistas, cosa que no podía perdonar el Presidente del $\mathrm{PNV}^{99}$; tapó sus carteles de propaganda ${ }^{100}$; insultó al Partido Nacionalista hasta el punto de que éste estaba confeccionando un dossier con sus insultos para poder presentarlo «dentro de dos meses, cuando llamen a nuestra puerta en busca de apoyos para el Gobierno de José María Aznar» ${ }^{101}$; basó su estrategia en «la satanización y demonización de los nacionalismos», que le llevó a Anasagasti a decir que «la política es también una cuestión de estilo y Aznar lleva mal camino para conseguir amigos» ${ }^{102}$; utilizaba un mensaje radical electoralista para avasallar a los grupos políticos vascos ${ }^{103}$; culpaba a los nacionalistas del descenso del nivel de renta del País Vas$\mathrm{co}^{104}$; no rectificaba las declaraciones de Arenas contra el Concierto Económico, lo que revelaba la «falta de convicción del Partido Popular» ${ }^{105} \mathrm{y}$, por supuesto, no hacía ningún esfuerzo por acercarse al PNV ${ }^{106}$.

96 El Correo 29-2-96 (24). Ver Deia 20-2-96 (3).

97 El Correo 19-2-96 (20).

98 El Correo 1-3-96 (24).

99 El Correo 20-2-96 (14). Ver El Mundo del País Vasco 20-296 (7) y Deia 21-2-96 (6).

100 El Correo 21-2-96 (23).

101 El Correo 23-2-96 (27). Ver, también, en El Correo 27-2-96 (20) las declaraciones de Anasagsti, que resaltan el lenguaje duro e insultante de Aznar contra el nacionalismo, a diferencia del utilizado por González.

102 El Correo 23-2-96 (27).

103 El Correo 27-2-96 (22).

104 El Correo 27-2-96 (22), donde se replica que fueron los grandes capitalistas los que abandonaron la industria pesada vasca a partir de 1970, «cuando empezó a no ser competitiva por falta de inversiones», según Arzalluz.

105 El Correo 29-2-96 (24).

106 El Correo 27-2-96 (20). 
Todo ello hacía responsable al Partido Popular del enfrentamiento y hostilidad entre ambos Partidos ${ }^{107}$ y le obligaría, después de las elecciones, a cambiar su discurso para poder llegar a algún entendimiento ${ }^{108}$. Pero, si el Partido Popular obtenía la mayoría absoluta, «ique Dios nos coja confesados!», exclamó Arzalluz en el mitin final de la campaña, porque «ino es verdad que el primer apaleado (por) la derecha española ha sido siempre el vasco? Por fortuna, en Europa ya no se pueden hacer hoy ciertas machadas como las que tuvieron que sufrir nuestros mayores, que lo pasaron mucho peor que nosotros» ${ }^{109}$.

Anasagasti pronosticó «una legislatura no apta para cardíacos», ya que la «derecha es fundamentalmente conspiradora» ${ }^{110}$.

Con respecto al segundo de los frentes, el del ultraconservadurismo, hay que matizar desde el primer momento que el PNV distinguió entre el Partido y su Presidente, por un lado, a los que no dudó de calificar de demócratas - aunque Anasagasti también afirmó que los demócratas del PP «son sólo unos pocos gramos» ${ }^{111}$ — e, incluso, refiriéndose a José María Aznar, de hombre honesto ${ }^{112}$ — de todos modos, «Aznar no es el centro, es la derecha» ${ }^{113}$ - y, por otro lado, determinada clientela integrada entre los populares. Fue, por supuesto, esta parte del Partido la más aireda y la más denunciada, como correspondía en una situación en la que lo que se disputaba era el voto de centro, el voto de la antigua UCD-CDS ${ }^{114}$. Este reconocimiento explícito se hizo, no obstante, con cierta reticencia, que, con ocasión de la disputa sobre quién era más demócrata, se expresó en los términos, ya utilizados en la República, de: «Aznar, los conversos a la cola» ${ }^{115}$. Esta reticencia se

107 Ibidem. En Deia 24-2-96 (4) se pide al PP «distensión verbal».

108 El Correo 1-3-96 (24).

109 El Correo 2-3-96 (21). Según el cronista del mitin, los jóvenes de EGI corearon las alusiones de Arzalluz al Partido Popular vueltos de espalda y diciendo: «Los del PP dan por el culo».

110 El País 27-2-96 (20).

111 Deia 25-2-95 (4).

112 Ver El Correo 28-2-96 (23). Esto fue compatible con la acusación de que «tuvo como máximo líder durante su juventud a José Antonio Primo de Rivera», acusación hecha en respuesta a Aznar por haber pedido a los seguidores del PNV ser primero «demócratas y luego nacionalistas» (El Correo 20-2-96 (14)).

113 El País 27-2-96 (20), entrevista a Anasagasti.

114 Ver El Correo 27-2-96 (20).

115 El Correo 20-2-96 (14). Ver El Mundo del País Vasco 20-2-96 (7). -En una crítica, más bien un exabrupto, muy habitual en Arzalluz, contra la campaña de los demás Partidos, éste dijo: «Se están enzarzando en todos los vicios de esta democracia, de esta Constitución que a veces nos muestran poco menos que como la Biblia salvadora, como si fueran demócratas de toda la vida, cuando la mayoría de ellos son aprendices, a disgusto, del sistema democrático» (El Correo 25-2-96 (32)).- Sobre la crítica a la democracia del PP ver: Deia 20-2-96 (3); Egin 20-2-96 (12) y El País 20-2-96 (20). 
manifestó, incluso, en palabras de Ardanza, que destacaron frente a la reciente imagen democrática del PP la solera de la democracia nacionalista. «El PP — dijo Ardanza - es un partido advenedizo, que tiene muy poquitos años y su presidente un político muy joven al que no han explicado que el PNV, durante una sublevación militar, defendió la legitimidad de una República con la que tuvo muchos problemas» ${ }^{116}$. Pero, el reconocimiento del carácter democrático no incluía el matiz de demócrata-cristiano ${ }^{117}$.

Esto supuesto, la campaña destacó a aquellas personas o elementos, que podían manifestar la condición ultraconservadora o poco democrática de los populares. Así, se denunció a Rodolfo Martín Villa, por haber impedido la investigación del GAL en el Senado, y al propio PP, «cuyo origen, como en el caso de Martín Villa, no es democrático, sino que representa la derecha de siempre» ${ }^{118}$. La mayoría de la militancia popular se había encontrado muy cómoda durante el franquismo y, así como el PNV no había tenido nunca «tentaciones fascistas», «los fachas españoles, que todavía quedan, están en el PP. ¿O es que están en el PSOE», dijo Arzalluz ${ }^{119}$.

Se atacaba a la derecha de siempre ${ }^{120}$, pero se pretendía desprestigiar al Partido Popular por darle cobijo. El aniversario del golpe del 23-F fue la ocasión para que Arzalluz dijese: «Ese día se hicieron listas de nacionalistas, no de ETA, a los que había que borrar del mapa (...) Si aquello hubiera triunfado, hoy no estaríamos nosotros aquí (...) Todos esos ahora son demócratas y votan $\mathrm{PP} \gg^{121}$. La posibilidad de la mayoría absoluta le hacía exclamar en el mismo mitin: «¿Cómo nos arreglaremos cuando salgan todos los demonios que tienen dentro, desde Botín al cacicato andaluz? Te comen. Si sacan la mayoría absoluta, habrá que ponerse un chubasquero hasta que pase la tormenta» ${ }^{122}$. Los vascos no podían esperar nada bueno del Partido Popular ${ }^{123}$.

116 El Correo 20-2-96 (14).

117 Ver El Correo 19-2-96 (20), El Mundo del País Vasco 20-2-96 (7) y El País 20-2-96 (20).

118 El Correo 19-2-96 (20). En Deia 19-2-96 (3) se acusa a Martín Villa de no haber hecho nada para reprimir a los incontrolados que «surgen siempre al calor de la Policía Nacional y de la Guardia Civil». Ver también Egin 19-2-96 (13) y El Mundo del País Vasco 19-2-96 (15).

119 El Correo 20-2-96 (14). En El País 20-2-96 (20) aparece un texto más completo: «Antes decían que había dos Españas; pues ahora hay media España. No hay más que centro, izquierda y periferia; la derecha falta, o sea que ¿dónde está?, ¿va a estar en el PSOE?»

120 Ver El Correo 24-2-96 (18), Deia 19-2-96 (3), 20-2-96 (3), Egin 19-2-96 (13), El Mundo del País Vasco 19-2-96 (15) y El País 20-2-96 (20).

121 El Correo 25-2-96 (32). Ver Deia 25-2-96 (3).

122 El Correo 25-2-96 (32).

123 Deia 25-2-96 (3). 
Anasagasti manifestó no sólo que los intereses principales de los vascos no coincidían con los del PP, sino que recelaba de la derecha, «que nunca ha intentado que los nacionalistas olvidemos el pasado. Sabemos muy bien que los dirigentes del PP no tienen nada que ver con el franquismo, pero también recordamos que la derecha económica de este país ha sostenido durante cuarenta años a la dictadura» ${ }^{124}$. A pesar de la sinceridad que se le reconocía a Aznar por centrar a su Partido, se le recordaba que olvidaba «que ahí están todos los que estaban», es decir, los franquistas. Por ello, «el día 3 de marzo, si ganan, le saldrá el banquero y el patrono tal y el cacique cual que dirán "hemos ganado y para qué, para volver a lo de antes"; si Aznar no puede dominar eso está perdido» ${ }^{125}$. No sólo, según Arzalluz, estaría perdido Aznar, sino, también, un posible entendimiento con los nacionalistas, ya que ésta era una de las condiciones para un posible acuerdo ${ }^{126}$. El ultraconservadurismo se traduciría en una política neoliberal que en materia de Estado de Bienestar supondría el desmantelamiento del mismo en su concepción clásica ${ }^{127}$.

El final de la campaña no mitigó los ataques al PP, a pesar de que era ya habitual hablar de la posible colaboración en el Gobierno. El PNV se presentaba como el freno de la derecha cerril y extremista, dispuesta a volver al régimen totalitario franquista ${ }^{128}$. Frente a las pretensiones totalitarias de los extremistas del PP, Aznar representaba el continuismo y, parodiándole con Julio Iglesias, se le dijo: «Aznar, igual que Julio Iglesias, quiere que la vida siga igual, y tiene poca voz, mucha parafernalia, mucho ruido y pocas nueces» ${ }^{129}$.

La tercera de las críticas manejó dos argumentos orientados a presentar al PP como incapaz de ejercer un Gobierno democrático. Estos argumentos eran la ocultación o carencia de programa y su inexperiencia.

«Yo no le oigo — declaró Arzalluz - decir a Aznar nada serio sobre lo que pretende hacer» en materia de lucha contra la violencia de ETA $^{130}$. El líder nacionalista pedía que se explicase la fórmula para solucionar el problema, que no consistiese en la mera aplicación de medidas de fuerza. El cumplimiento íntegro de las penas, la reforma del

124 El Correo 27-2-96 (20).

125 El Correo 28-2-96 (23).

126 Ibidem.

127 Deia 23-2-96 (8).

128 El Correo 1-3-96 (24). Ver, también, El Correo 2-3-96 (1).

129 El Correo 1-3-96 (24). Ataques contra Mayor Oreja se contienen en El Correo 22-2-96 (27), 27-3-96 (22), 1-3-96 (24) y El Mundo del País Vasco 22-2-96 (18).

${ }^{130}$ El Correo 18-2-96 (38). 
código penal, la introducción de la pena de muerte y la vuelta a los estados de excepción, «todo eso ya lo hizo Franco y no parece que lograra terminar con esta gente»131. Tal proyecto no era compatible con el Pacto de Ajuria Enea ${ }^{132}$ y, además, «contra ETA como contra todo, primero hay que poner la inteligencia y muy luego la dureza y la fuerza» ${ }^{133}$. Lo que había que evitar era la política de querer monopolizar la firmeza contra el terrorismo, que practicaban el PP y los Partidos de ámbito general. Tal estrategia, unida al jaleamiento de las acciones del juez Garzón contra HB y su portavoz, Jon Idígoras, era electoralista, ya que ir contra ETA daba votos, pero hacía el «caldo gordo», según Arzalluz, a los radicales ${ }^{134}$. «Lo duro vende - manifestó Arzalluz-, pero, contra ETA, antes hay que utilizar la inteligencia que la dureza» ${ }^{135}$. El PNV insistió también, en rechazar la política de aislamiento social del mundo radical, atribuida a Mayor Oreja. Todos los grupos sociales eran necesarios para la construcción de Euskadi, incluso los simpatizantes de HB que aceptasen las reglas del juego democrático. Anasagasti afirmó que Mayor Oreja pretendía que HB padeciese «la misma deslegitimación que ha sufrido él por ser un hijo del franquismo sociológico» ${ }^{136}$.

Aznar no ofrecía un programa claro, pero sí muchas promesas, de cuyo cumplimiento se dudaba. Practicaba una política «barbilampiña» y desconocía, juntamente con todos los del PP, lo que era el País Vasco y ETA. En una injusta y grosera descalificación por las medidas de seguridad con las que actuaban los políticos del PP en el País Vasco, fruto de tal desconocimiento, Arzalluz afirmó: «Vienen aquí como si esto fuera Sarajevo y luego se permiten ir de valientes ${ }^{137}$.

131 Ibidem. Ver, también, El Correo 24-2-96 (18), Deia 22-2-96 (6) y 28-2-96 (7), donde se rechaza la política antiterrorista meramente policial del PP contra ETA.

132 Ibidem.

133 El Correo 24-2-96 (18). Ver Deia 24-2-96 (3) y El Mundo del País Vasco 24-2-96 (14). Arzalluz recordó la defensa de la reindustrialización como política del Pacto de Ajuria Enea «para que la juventud no se quede en el paro y no vaya de las filas de los desesperados a los de la pistola» (El Mundo del País Vasco 22-2-96 (18)).

134 El Correo 25-2-96 (32).

135 El Correo 24-2-96 (18).

136 El Correo 1-3-96 (24).

137 El Correo 22-2-96 (27). Sobre indefinición y promesas incoherentes ver: Egin 17-2-96 (11), Deia 26-2-96 (3), El Mundo del País Vasco 26-2-96 (19) y Egin 26-2-96 (12). Según Anasagasti, un líder del PP le había comunicado que se hablaba poco del programa «porque así se suma más gente» (El País 27-296 (20), entrevista en la que también se afirma que el PP hablaba poco de las personas del futuro Gobierno «porque todo aquel que queda excluido empieza al día siguiente a conspirar», lo que le había permitido al político nacionalista sentenciar que «la derecha es fundamentalmente conspiradora»). 
La ocultación de las verdaderas intenciones o la ambigüedad en materia autonómica definía la campaña popular ${ }^{138}$. Pero no sólo se ocultaba la futura política autonómica, sino que, de acuerdo con los demás Partidos, se eludía el debate sobre la moneda única o la organización del Ejército y la Defensa, convirtiendo la campaña en un «comadreo». En lugar de debatir las grandes cuestiones, se asustaba a los jubilados hablándoles de las pensiones y los Partidos se enzarzaban «en todos los vicios de esta democracia, de esta Constitución que a veces nos muestran poco menos que como la Biblia salvadora» ${ }^{139}$. No había nada claro en el PP y el futuro era una incertidumbre ${ }^{140}$.

La conclusión de esta crítica al Partido Popular era clara. Había que frenar la «avalancha», anunciada por las encuestas, de un Partido, cuyo máximo dirigente tenía mentalidad de rodillo. De ahí que el PNV solicitase el voto útil e, incluso, el voto de los simpatizanes y votantes de Eusko Alkartasuna ${ }^{141}$.

\section{Herri Batasuna}

Fue el segundo Partido o Coalición más criticado con un $23,45 \%$ de este apartado, es decir, un $12,62 \%$ del total de campaña.

El guión seguido en la crítica a HB fue el siguiente: denuncia de los ataques y amenazas de los que era objeto el PNV y sus miembros; rechazo de la estrategia del MLNV; definición de su ideología como integrista; llamada a los críticos de HB y, por último, justificación de la petición del voto en la victoria sobre HB.

Nacionalistas del PNV fueron atacados por miembros de $\mathrm{HB}$ o de Jarrai con botes de pintura, que alcanzaron a jóvenes de EGI y una furgoneta. De la misma manera que el PP había tapado los carteles de propaganda, así mismo lo hizo $\mathrm{HB}$, «pero hemos evitado llevar el enfrentamiento a la opinión pública para no radicalizar la campaña», se comentó en un comunicado del PNV ${ }^{142}$.

138 El Correo 23-2-96 (27). En opinión de Emilio Olabarría el PP generaba desconfianza para desarrollar el Estatuto y era más centralista que el PSOE (Deia 23-2-96 (8)).

139 El Correo 25-2-96 (32). Sobre la campaña, anómala, difícil, aburrida y sin debates ver: Deia 19-2-96 (3), 20-2-96 (3), 22-2-96 (6), 23-2-96 (6), 27-2-96 (3); Egin 19-2-96 (13), 27-2-96 (10), 2-3-96 (14); El Mundo del País Vasco 19-2-96 (15). En Deia 24-2-96 (4) y 28-2-96 (6): críticas por copiar a Chirac el tema de la profesionalización del Ejército.

140 Ver El Correo 26-2-96 (20).

141 Ver El Correo 27-2-96 (22) y 1-3-96 (24) y Deia 25-2-96 (3), más lugares citados en la crítica a EA.

142 El Correo 21-2-96 (23). 
Arzalluz, testigo de la disolución de un centenar de jóvenes radicales, que habían pretendido acercarse al local, en Llodio, donde se celebró un acto político del PNV, manifestó que es «mejor que ellos nos tiren tiros; ya nos han matado a más de uno, y no que empecemos a matarnos nosotros como está pasando en Córcega» ${ }^{143}$. La exclamación de "iqué más quisieran fuera de aquí» (o «lo que alegraría a muchos de por allí»), dicha en relación a la posible respuesta con violencia a la violencia, era una grave acusación y una explicación importante de la estrategia nacionalista $^{144}$. Las amenazas contra Atutxa, el Lehendakari, Anasagasti y el propio Arzalluz — «nos pusieron en el punto de mira»- hicieron que éste declarase: «Nos tachan, nos quieren matar como parte del sistema porque somos demócratas. Que vengan sin careta nacionalista y si nos tienen por vascos, que sepan que al vasco, por las buenas mucho, por las malas, nada» ${ }^{145}$.

La estrategia de ETA era clara; consistía en «liberar a Euskadi con el tiro en la nunca de un peatón» ${ }^{146}$, en traer la ruina a la espera de que provocase «el cabreo general y el levantamiento» ${ }^{147}$ y en utilizar a los presos y sus familiares en una «estrategia de explotación del sufrimiento», que ocultaba su «incapacidad de iniciativa política», o, lo que es lo mismo, una dirección propia de «revolucionarios de fin de semana o a media jornada» 148 .

Tales manifestaciones se completaban con la tesis de que la campaña estaba girando, después de un comienzo polarizado en torno a Felipe González y José María Aznar, sobre el MLNV, que había puesto en ella dos asesinatos, a Garzón, a Idígoras y el vídeo de ETA ${ }^{149}$. Se estaba haciendo

143 El Correo 22-2-96 (27). En Deia 22-2-96 (6) se recoge el siguiente texto acusatorio contra el sujeto, en un sentido, indeterminado de los de «fuera de aquí»: «Nosotros aguantamos más porque los más sensatos tenemos que aguantar más. Lo último que pediría yo es que empezáramos a tiros con ellos. ¡Qué más quisieran fuera de aquí! Es mejor que nos disparen ellos». En El Mundo del País Vasco 22-2-96 (18) se dice: «para ésos somos un padre; yo no quiero ser padre de ésos, pero de cara al país los que tenemos que tener cabeza somos nosotros y lo último que debe pasar y que alegraría a muchos de por allí es que nosotros empezáramos a tiros con éstos». Ver Deia 18-2-96 (6).

144 Ver nota anterior.

145 El Correo 2-3-96 (21).

146 El Correo 24-2-96 (18). Ver Deia 24-2-96 (3).

147 Deia 24-2-96 (3). En El Mundo del País Vasco 24-2-96 (11) se llama a los de KAS «esos de la liberación».

148 El Correo 24-2-96 (18). En Deia 24-2-96 (3) se recogen, además, declaraciones que destacaban la suficiencia de «instrumentos para atajar la impunidad de los violentos». En Egin 25-2-96 (12): no interesa a ETA la salida de los presos. Ver El Mundo del País Vasco 25-2-96 (31).

149 El Correo 27-2-96 (22). Ya en Deia 16-2-96 (10) se recogía la crítica de que se hiciese a ETA la propaganda que necesitaba. Ver también Egin 17-2-96 (11). 
la campaña a ETA y $\mathrm{HB}^{150} \mathrm{y}$, en concreto, la política anti $\mathrm{HB}$ realizada desde Madrid podía devolverle los votos de los que se iban a abstener hartos de tanta violencia, razón por la que los de HB andarían «contentillos — según Arzalluz- por los últimos acontecimientos» ${ }^{151}$.

González de Txabarri calificó la campaña propiamente dicha de HB de «terrorismo puro y duro» ${ }^{152}$, que pretendía en las elecciones del 3 de marzo saber cuántos mayores de 18 años apoyaban a ETA en el País Vasco.

En la estrategia del sufrimiento, en este caso, apariencia de sufrimiento, Arzalluz situó la pretensión de Idígoras y Aoiz de que los metiesen en la cárcel. Una vez en ella Idígoras, Arzalluz comentó que deberían «cobrarle un tanto por día de cárcel. ¡Nada de fianza por salir! Ahí tenéis a Idígoras hecho un héroe» ${ }^{153}$. La actitud de ambos radicales había sido un provocación a la Justicia, pero «si realmente tuvieran algo gordo detrás, se habrían ido, como han hecho otros» ${ }^{154}$.

En el último día de campaña Arzalluz recordó que «Idígoras es ahora el mártir de esta gente que no trae nada y que quiere vivir esperando no sé qué, como en la guerra de los cien años» ${ }^{155}$ porque todo lo que había aportado HB en los últimos años había sido «sufrimiento, sangre, crispación y un vídeo» ${ }^{156}$. El encarcelamiento de Idígoras revitalizaba a $\mathrm{HB}^{157}$.

Para Arzalluz el nacionalismo de HB era una careta, mientras que lo que definía al tándem ETA-HB era el integrismo. El mitin de HB en Anoeta, que había sido una «pastoral suletina en negro»158 («una pastoral negra para adolescentes» $)^{159}$ y un «espectáculo ritual», fue, también, un

150 Deia 16-2-96 (10) y El País 18-2-96 (19), donde también se recoge el criterio del PNV, muy repetido durante la campaña, contrario a la ilegalización de HB. Ver, asimismo, Deia 19-2-96 (3), Egin 19-2-95 (13) y El Mundo del País Vasco 19-2-96 (15).

151 Deia 29-2-96 (5). Ver El País 27-2-96 (20 y 21).

152 El Correo 27-2-96 (22).

153 El Correo 24-2-96 (18). Arzalluz comparó la detención de Idígoras con la que años antes se había hecho con Telesforo Monzón: «Le hicieron la campaña electoral cuando lo encarcelaron y todos temíamos que le diera un infarto» (Ibidem). Ver también Deia 24-2-96 (3 y 10) y Egin 24-2-96 (10) y 25-2-96 (12).

154 El Correo 25-2-96 (32). Ver también El País 25-2-96 (26); Egin 25-2-96 (12).

155 El Correo 2-3-96 (21).

156 El Correo 23-2-96 (27). Arzalluz calificó de lógica la intervención de Garzón por el vídeo, porque era «un instrumento delictivo de apología del terrorismo», pero desde el punto de vista político-práctico lo mejor habría sido permitir su difusión «para que se hubiera visto la poca cosa que es» (El Correo 17-2-96 (16)).

157 El Mundo del País Vasco 29-2-96 (14-16). En Deia 26-296 (4) Anasagasti califica de absurda por el momento político la detención de Idígoras.

158 El Correo 2-3-96 (21).

159 Deia 29-2-96 (3). 
«copiado del IRA, en el que la gente se enardece con pasamontañas, serpientes y vídeos... para crecerse en su integrismo» ${ }^{160}$.

En el comunicado de ETA, mediante el que se pretendía justificar el asesinato de Múgica, el Presidente del PNV vio «la intolerancia, el monopolio de lo que es ser nacionalista, independentista, revolucionario o vasco, como si Múgica no fuera vasco, como si un vasco no (tuviera) derecho a ser liberal, a ser socialista o lo que sea siendo vasco» ${ }^{161}$. La «fachenda» vasca, el fascismo, no sólo estaba en el PP, sino también en Herri Batasuna ${ }^{162}$.

Con razón se dijo en la campaña que contra la violencia había que usar más la inteligencia que la fuerza y las medidas policiales. Tal vez, por ello, Egibar invitaba a los votantes de HB a que hiciesen una reflexión profunda para dar «un golpe de timón» en la estrategia del MLNV. Había que abogar por las voces críticas en la izquierda radical, ya que HB estaba centrada en una «estrategia de resistencia, sin salida, y con unas relaciones de endogamia sin conexión con el resto de la sociedad» 163 .

Completando esta intervención, Olabarría declaró: «Tienen enfrente a todos los partidos, a todos los sindicatos, a todas las asociaciones empresariales, a los presos comunes, a todos los gobiernos del mundo democrático, ¿qué más necesitan escuchar para que paren en su sinrazón» ${ }^{164}$.

La victoria electoral del PNV en Guipúzcoa se interpretaba como un freno a los violentos y como una bandera menos para $\mathrm{HB}^{165}$.

\section{Partido Socialista Obrero Español}

Hubo un cierto reconocimiento positivo del Partido Socialista y de su Presidente, Felipe González, que, más bien, parece que se hizo para resaltar comparativamente el rechazo y las críticas al Partido Popular ${ }^{166}$.

160 El Correo 29-2-96 (24). En Deia 28-2-96 (6) González Txabarri afirma que «lo único que HB no hizo en Anoeta fue inmolar un cordero». En El País 26-2-96 (22) Arzalluz califica el acto de Anoeta de «pastoral política» dirigida a la juventud. Así, «se aumenta el odio y se enarcede a la gente. Les ves dispuestos a cualquier cosa, y eso me preocupa». En El Mundo del País Vasco 29-2-96 (14-16) Arzalluz manifiesta que no había riesgo de enfrentamiento civil en Euskadi.

161 Deia 25-2-96 (3). Ver El Mundo del País Vasco 25-2-96 (34).

162 El Mundo del País Vasco 29-2-96 (14-16).

163 El Correo 24-2-96 (18).

164 Deia 22-2-96 (6).

165 Ver El Correo 27-2-96 (22), 29-2-96 (24) y 2-3-96 (21); Deia 26-2-96 (4) (voto útil contra HB y PP), 27-2-96 (3), 1-3-96 (5) (frenar al PP y HB) y Egin 27-2-96 (10).

166 Ver en este sentido El Correo 27-2-96 (20), 29-2-96 (24); Deia 27-2-96 (3); El Mundo del País Vasco 29-2-96 (12). 
Porque lo que se dijo con rotundidad fue que el pasado político protagonizado por los socialistas estaba agotado, que la experiencia con ellos había sido mala y, también, que el Partido Socialista no era, precisamente, un amigo de los nacionalistas ${ }^{167}$.

Se le acusó de haber abandonado la industria de la margen izquierda, de no haber completado el Estatuto de Gernika ${ }^{168}$, de haber incumplido muchas promesas, de haber estado a punto de hundir a la pequeña industria vasca ${ }^{169} \mathrm{y}$ de ineficacia en la lucha contra ETA ${ }^{170}$. Además, el PSOE había impedido que el PNV fuera compensado por los bienes incautados por el franquismo. "Los socialistas se van sin devolvernos una peseta, cuando ellos han cobrado 66.000 millones»-dijo Arzalluz- y, añadiendo una nueva materia no sujeta al perdón, comentó: «eso es algo que jamás les perdonaré» ${ }^{171}$.

Pero, si nos atenemos a las expresiones formales, la mayor acusación fue la de «aquella euforia, aquella prepotencia del 92, donde se enterraron billones, más por conmemorar el decenio socialista que por otra cosa» ${ }^{172}$.

Otros aspectos negativos coincidían con los denunciados contra el PP, que ya se han anotado: la conversión de la campaña en un comadreo, que impedía el debate de las grandes cuestiones, y la caída en los males de la democracia española y de la Constitución vigente, además de la confusión del nacionalismo con la violencia y del ridículo de otras fobias antinacionalistas ${ }^{173}$.

Pero hubo una acusación grave, común al PP y al PSOE, que atribuía a ambos la preferencia de unos buenos resultados electorales para Herri

167 Ver El Correo 26-2-96 (20) y Deia 26-2-96 (3). En El Mundo del País Vasco 24-2-96 (11): «No han sido nuestros amigos, aunque pasan por serlo».

168 La idea de Rodríguez Ibarra de paralizar el Estatuto vasco, mientras existiese ETA, mereció este comentario de Arzalluz: «Esto es precisamente lo que quiere ETA... Lo mejor que puede hacer Rodríguez Ibarra es dedicarse a lo suyo, a fomentar el corcho y la ganadería, a industrializar Extremadura. Que no hable de lo que no entiende, como yo no lo hago del corcho» (Deia 18-2-96 (6)).

169 Ver El Correo 23-2-96 (27), 24-2-96 (18), 26-2-96 (20) y 27-2-96 (22). En Deia 21-2-96 (5) y El Mundo del País Vasco 212-96 (13): sobre la defensa de la margen izquierda en Madrid. En El Mundo del País Vasco se acusa a Eguiagaray de no haber tratado de compensar, orientando inversiones hacia Euskadi, la desventaja vasca por culpa de la violencia de ETA. En El Mundo del País Vasco 24-2-96 (11) y Deia 25-2-96 (3): sobre el Estatuto. En Deia 24-2-96 (3) se lee: «Hace tres años — dijo Arzalluz — intentamos entrar en el riesgo de la administración de estas empresas en crisis (de la margen izquierda), pero los socialistas no nos dejaron meter ni la oreja».

170 Ver El Correo 19-2-96 (20).

171 El Correo 26-2-96 (20).

172 Deia $17-2-96$ (7).

173 Ver El Correo 25-2-96 (32) y 17-2-96 (24). 
Batasuna, acompañados del descenso del Partido Nacionalista, «porque en el día a día parlamentario, HB no representa ningún problema porque no va a Madrid». La política seguida con respecto a HB durante la campaña con las detenciones y el vídeo de ETA, repitiendo el fenómeno de la detención de Telesforo Monzón en las elecciones de 1979, demostraría la validez de semejante acusación ${ }^{174}$.

\section{Eusko Alkartasuna}

El rechazo de candidaturas conjuntas y la dispersión del voto nacionalista a que daba lugar fueron los motivos electorales criticados contra EA. Su actitud favorecía al PP y a HB, especialmente en Guipúzcoa. Resultaba absurda, según Arzalluz, la división nacionalista, cuando apenas existían diferencias entre ambos Partidos. La escisión era cosa del pasado y la divisón actual convertía el voto a EA en un voto inútil para el nacionalismo ${ }^{175}$. La fragmentación del voto a que daba lugar EA en Guipúzcoa no se correspondía con la estructura social ${ }^{176}$. De ahí las llamadas a concentrar el voto nacionalista en el $\mathrm{PNV}^{177}$, porque sería «una vergüenza que quienes están sustentando el terrorismo aquí, puedan estar por delante en votos» ${ }^{178}$.

Pero también se censuró la mera existencia de EA, porque resultaba «perjudicial para el nacionalismo la existencia de dos partidos ideológicamente idénticos» ${ }^{179}$. Emilio Olabarría llegó a decir que «la construcción de una patria cohesionada requiere la unidad de todos los nacionalistas. EA sólo perjudica el avance del nacionalismo» ${ }^{180}$. Y, yendo más allá en el riesgo de las interpretaciones, Xabier Albistur manifestó que «si hubiera una única lista nacionalista en Gipúzcoa HB sería absolutamente marginable y la violencia sería un problema inferior» ${ }^{181}$.

De todos modos, no se esperaban grandes dificultades para una colaboración en las Cortes, ya que «al final, política y sociológicamente, el PNV y EA somos lo mismo», manifestó Gangoiti, quien añadió que «si hoy fuéramos un partido único como lo fuimos antes, el domingo

174 Deia 1-3-96 (4), entrevista a Jon Gangoiti.

175 Ver Deia 17-2-96 (7) y Egin 17-2-96 (11). Ver, también, Deia 22-2-96 (6).

176 Deia 28-2-96 (6).

177 Deia 1-3-96 (5). Ver, también, Deia 16-2-96 (10); 17-2-96 (7).

178 Deia 18-2-96 (6); ésta es una de tantas repeticiones textuales de la campaña del 93.

179 Deia 22-2-96 (6).

180 Deia 23-2-96 (8). Algo parecido dijo Egibar al afirmar que la dispersión del voto nacionalista, incluyendo el voto a HB, impedía el desarrollo estatutario (Deia 23-2-96 (6)).

181 Egin 25-2-96 (12). 
obtendríamos un diputado más en Bizkaia, otro más en Araba y tres senadores más en Araba. Realmente habría un Grupo Vasco fuerte en Madrid ${ }^{182}$.

Anasagasti prefirió no opinar sobre EA. Su objetivo era colaborar con el Partido de Garaikoetxea, Partido que le parecía una opción legíti$\mathrm{ma}^{183}$.

\section{La campaña de Eusko Alkartasuna}

\section{Datos básicos o generales}

La parte dedicada a la crítica de los Partidos Políticos tuvo en EA más extensión que la dedicada a dar cuenta de su identidad o imagen de Partido. Esta alcanzó el 45,56\% de la campaña frente al 54,43\% de la primera.

El nacionalismo con sus temas afines o cercanos llenó el 40,71\% de la identidad de EA, un $18,55 \%$ del total de su campaña. Se incluyen aquí el Estatuto, el autogobierno, la autodeterminación, la independencia, las relaciones bilaterales entre Estado y País Vasco, la cuestión de Navarra y la unidad del nacionalismo. Las cuestiones o temas no nacionalistas — violencia, pacificación, Estado de Bienestar o mujer, entre otros-ocuparon el 55,89\%, lo que representó el $25,46 \%$ del total. Como ocurrió en la campaña del Partido Nacionalista, la pacificación supuso más de los $2 / 3$ de este apartado. Lo relativo al apartado de acción de Gobierno fue prácticamente inexistente o anecdótico, 3,39\% y $1,54 \%$ respectivamente, y se redujo, en todo caso, a defender la utilidad del voto a EA para futuras actuaciones durante la legislatura o a destacar la dificultad e, incluso, imposibilidad de una acción común con el PNV en las Cortes ${ }^{184}$.

La mayor parte de la crítica a los Partidos Políticos se centró sobre el Partido Nacionalista Vasco y Herri Batasuna. El primero mereció una atención del 42,89\% de esta parte, que supuso el 23,35\% del total de la campaña. Por su parte, Herri Batasuna y ETA tuvieron un espacio del $34,37 \%$, es decir, el $18,71 \%$ del total. La atención crítica prestada a los demás Partidos fue muy inferior; $8 \%$ para el Partido Socialista $(4,39 \%$ del total), 5,82\% para el Partido Popular (3,17\% del total) y $8,81 \%$ dirigida a todos los Partidos en general (4,80\% del total).

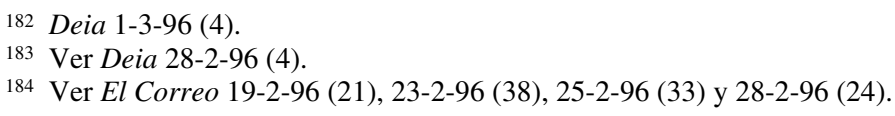


Por lo que se refiere a la participación de los políticos en la campaña hay que destacar la actuación de Carlos Garaikoetxea con casi el 50\% del total recogido por la prensa; a continuación vienen los nombres de J. Iraragorri e I. Oliveri; Martínez de Luna y B. Lasagabaster tuvieron una menor actividad, a la que se unió la colaboración de Rahola.

\section{El desarrollo de la campaña}

A) La imagen o identidad de Eusko Alkartasuna

\section{El contenido nacionalista}

Las materias incluidas en este apartado tuvieron un tratamiento parecido en extensión, si se exceptúan el autogobierno, que superó la media, y la unidad del nacionalismo, que recibió poca atención.

La independencia política era el objetivo final, tal como se defendió en el acto que cerró la campaña ${ }^{185}$, y un supuesto permanente en las argumentaciones tanto contra el Partido Nacionalista como contra la coalición de Herri Batasuna y los llamados Partidos estatales. Y, como se había dicho en otras ocasiones, la independencia no sólo era un derecho que correspondía a los vascos, sino, también, un instrumento eficaz para solucionar los problemas de los mismos. Su inexistencia explicaba - juntamente con la violencia y la incapacidad de determinados grupos dirigentes que «no fueron capaces de reorientar sectores industriales bajo su control, trasladando funciones directivas y departamentales de empresas importantes»-, las decisiones políticas que impusieron el sacrificio de sectores estratégicos de la industria vasca. De ahí se deducía «la trascendencia de la dependencia o independencia política» ${ }^{186}$. No obstante la importancia objetiva concedida a la independencia, se reconocía la dificultad, por motivos subjetivos, de trasladar a la sociedad vasca el proyecto independentista, ya que no todos se sentían «exclusivamente vascos». Pero, aunque los objetivos últimos de EA —el autogobierno o la independencia - no debían ser sólo para los nacionalistas, sino para todos los vascos, el problema estaba en

185 Ver El Correo 2-2-96 (22). En El Correo 27-2-96 (23) aparece la defensa de la soberanía política con métodos democráticos y pacíficos. Ver, también, El Correo 25-2-96 (36). En Deia 20-2-96 (7) se defiende el Estado vasco unificado e independiente y en $\mathrm{El}$ Mundo del País Vasco 29-2-96 (12) Garaikoetxea afirma que, ante las grandes áreas de ejercicio común del poder en el contexto internacional, hay otras de soberanía política que ninguna nación abandonará por ser el instrumento de su propia permanencia como pueblo.

186 El Correo 18-2-96 (39). 
la falta de conciencia únicamente vasca. Como el proyecto nacionalista de EA era integrador, en palabras de Oliveri, había que empezar por crear un único sentimiento, una única conciencia, la de ser exclusivamente vascos, es decir, la de ser nacionalistas. «Nuestro proyecto - dijo Oliveri- es integrador, por lo que debemos hacer una labor didáctica para que todos los vascos sientan la necesidad de decidir por sí mismos» ${ }^{187}$.

Por otra parte, la violencia estratégica del abertzalismo radical no era motivo para que EA ocultase sus objetivos políticos. No había que «arrinconar y ocultar nuestras reivindicaciones legítimas por decir no a quienes, por un procedimiento ilegítimo, piden las mismas cosas» ${ }^{188}$.

El autogobierno para todos los vascos, defendido en la campaña, fue un concepto un tanto indeterminado, que lo mismo podía entenderse como autonomía que como soberanía o, también, como proceso de profundización de la autonomía para llegar a la soberanía o, simplemente, se identificaba con autodeterminación. Esta indeterminación o utilización polisémica del término se dio, cuando Garaikoetxea anunció que su Partido promovería en la siguiente legislatura, juntamente con Esquerra Republicana de Catalunya y del Bloque Nacionalista Galego, un debate constitucional sobre el autogobierno para reivindicar una mayor autonomía para las nacionalidades históricas. Ahora bien, este mismo debate permitiría demostrar a los Partidos de ámbito general —que «nos han chantajeado para silenciarnos, con acusaciones de dar pábulo a los violentos»- la posibilidad de defender pacífica y democráticamente la soberanía ${ }^{189}$. También se mostró aquella misma condición al afirmarse que el autogobierno no era ni «una utopía ni un cuento romántico» ${ }^{190}$. Más cerca de identificar autogobierno con independencia parece que está la intervención de I. Oliveri a la que antes me he referido ${ }^{191}$. Pero Oliveri expresamente dijo que «entendemos el autogobierno como instrumento político para el desarrollo de este país. Somos una comunidad nacional diferenciada y, por tanto, el autogobierno que entendemos es que no hay más límite que la voluntad mayoritaria de los vas$\cos ^{192}$ », con lo que el autogobierno parecía identificarse con la voluntad popular vasca o, simplemente, con autodeterminación. Sin embargo, al hablar del voto útil se utilizó el término en sentido de profundización de

187 El Correo 2-2-96 (22).

188 El Correo 19-2-96 (21). Ver también declaraciones de Garaikoetxea a El Mundo del País Vasco 28-2-96 (15) en el mismo sentido.

189 El Correo 27-2-96 (23).

190 El Correo 29-2-96 (25).

191 Ver El Correo 2-3-96 (22).

192 El Mundo del País Vasco 1-3-96 (13). 
la autonomía ${ }^{193}$. Y para mayor confusión, el mismo Oliveri afirmó que «la única salida que tiene el autogobierno real para el País Vasco es la relación bilateral con el Estado»194, lo que suponía situar el autogobierno al margen del planteamiento general de la autonomía. En cualquier caso, había que defender los derechos de los vascos, que tenían «problemas distintos a los del resto del Estado» ${ }^{195}$, y la identidad del pueblo vasco desde la Unión Europea «para evitar que la cultura más antigua de Europa occidental (se perdiese), y con ella nuestra identidad de pueblo» ${ }^{196}$. La presencia de EA en las Cortes obedecía a que «hoy por hoy» era imprescindible estar en tal foro para defender los intereses del País Vasco ${ }^{197}$. La mejora de la situación económica y social del País Vasco y la no dependencia (o independencia) de «intereses ajenos a nosotros» eran otros frutos que se asociaban al autogobierno ${ }^{198}$.

La clave del sistema, aunque no la prioridad, estaba en la autodeterminación. No sólo la dignidad de la persona estaba por encima de cualquier otro objetivo, incluida la autodeterminación, afirmación que parecía decirse con carácter absoluto ${ }^{199}$, sino, también, la pacificación. Al menos, para la siguiente legislatura la normalización de Euskadi era el primer objetivo, aunque Eusko Alkartasuna, afirmaba su presidente, era la única formación «nacional vasca comprometida con el derecho de autodeterminación» 200 , defendido por medios pacíficos y democráticos ${ }^{201}$. Plantear la autodeterminación, respetando la voluntad mayoritaria de los

193 Ver El Correo 28-2-96 (24). En esta misma información, Iraragorri habría defendido, según recensión de El Correo, el desarrollo íntegro del Estatuto para evitar que Euskadi siguiese «a merced de decisiones ajenas», añadiendo a continuación la defensa del aumento de los instrumentos de autogobierno «para no depender de intereses ajenos a nosotros». En El Correo 24-2-96 (19) parece establecerse una relación progresiva entre autonomía, autogobierno y libertades de los vascos. En El Correo 28-2-96 (24) se identifica el voto útil con el compromiso por un mayor autogobierno y la autodeterminación. Egin 21-2-96 (14) informaba que Begoña Lasagabaster defendió el autogobierno «total» para más tarde, con la voluntad mayoritaria de los vascos, «acceder al derecho de autodeterminación» $\mathrm{y}$, «a medio o largo plazo a la independencia».

194 El Correo 21-2-96 (23).

195 El Correo 25-2-96 (36). En general, todas las informaciones sobre EA de El Correo 25-2-96 aparecen en Deia 25-296 (10); las de El Correo 26-2-96, en Deia 26-2-96 (6), en El Mundo del País Vasco 26-2-96 (13) y en El País 26-2-96 (22); las de El Correo 29-2-96, en Deia 29-2-96 (7) y Egin 29-2-96 (14); las de El Correo 1-3-96, en Deia 1-3-96 (8) y El Mundo del País Vasco 1-3-96 (13).

196 El Correo 25-2-96 (36). En Egin 23-2-96 (14) se pide voz y voto en la UE.

197 Ver El Correo 25-2-96 (36).

198 El Correo 16-2-96 (24).

199 Ver El Correo 17-2-96 (24) y 25-2-96 (33), donde Garaikoetxea afirma que «en EA, por encima de las ideologías, colocamos siempre la dignidad de las personas».

200 El Correo 17-2-96 (24). La defensa de la autodeterminación aparece, también, en $\mathrm{El}$ Correo 18-2-96 (39), 19-2-96 (21), 20-2-96 (15), 25-2-96 (36), 28-2-96 (24).

201 El Correo 16-2-96 (24). 
vascos, constituía un riesgo, que Eusko Alkartasuna estaba dispuesto a correr, porque se trataba de un elemento de la democracia, según razonaba J. Iraragorri, al decir que «ser demócrata significa ante todo respetar cualquier idea, admitir ese derecho (autodeterminación) y comprometerse a asumir el resultado de la voluntad popular» 202 .

A la vez que se afirmaba que la violencia hacía difíciles las inversiones extranjeras en Euskadi, se mantenía, también, que con la defensa del derecho de autodeterminación se apoyaba «el progreso económico y social de Euskal Herria» ${ }^{203 .}$ No podía extrañar, según esto, que el voto útil nacionalista se hiciese coincidir con el voto a EA, precisamente por defender mayores cotas de autogobierno y el derecho de autodeterminación $^{204}$. El objetivo, por el contrario, de la defensa del derecho de autodeterminación no era acercarse al mundo de ETA. Simplemente se pretendía que se reconociese a los vascos el derecho de autodeterminación recogido en la Carta de las Naciones Unidas ${ }^{205}$.

Coincidiese o no el autogobierno con la autonomía, en la campaña se defendieron claramente ambos conceptos. Por lo que respecta al segundo, el desarrollo del Estatuto de Autonomía debía ser íntegro, ya que Euskadi no podía seguir «a merced de decisiones ajenas» ${ }^{206}$. Por ello, EA se comprometía a exigir del gobierno central, además de la realización del programa de infraestructuras, la transferencia de las competencias estatutarias pendientes ${ }^{207}$, cosa que no había ocurrido hasta entonces «por falta de voluntad política de Madrid» ${ }^{208}$. La autonomía parecía entenderse

202 El Correo 20-2-96 (15). Ver El Mundo del País Vasco 20-2-96 (7); Egin 18-1-96 (15): la autodeterminación es progreso; El Mundo del País Vasco 21-2-96 (14: autodeterminación y vocación europeísta) y 28-2-96 (15: donde Garaikoetxea declara: «...Creemos que si existiera la opción deseable de ejercer el derecho de autodeterminación, la comunidad autónoma (vasca) debería estar en condiciones de ejercerlo, pero habría que establecer simultáneamente la opción permanente del resto de Euskal Herria a poder incorporarse a ese proyecto político... Lo importante es que todo el mundo sepa que hoy, mañana o pasado mañana, habrá un cauce legal para que la voluntad mayoritaria del pueblo vasco tenga su reconocimiento y respeto»).

203 El Correo 18-2-96 (39). Ver también Deia 18-2-96 (9).

204 Ver El Correo 28-2-96 (24); Egin 2-3-96 (14). También se defendió el voto a EA para romper la polarización entre PSOE y PP: Ver Deia 17-2-96 (8) y Egin 17-2-96 (11).

205 Ver en El Correo 25-2-96 (36) entrevista a Jasone Iraragorri.

${ }^{206}$ El Correo 16-2-96 (24). Se trata de afirmaciones imprecisas e, incluso, erróneas tanto política como jurídicamente. En Egin 24-2-96 (12) se reclama la transferencia de medio ambiente; en El Mundo del País Vasco 28-2-96 (15) Garaikoetxea se refiere a la «interpretación de alcances insospechados» que, «con voluntad política», posibilita la Disposición adicional del Estatuto y al hecho de que «el Estatuto ha quedado tocado del ala con ese entramado de leyes básicas, mucho más que con el hecho de que estén pendientes cuarenta y pico transferencias».

207 Ver El Correo 18-2-96 (39).

208 El Correo 21-2-96 (23). Ver también Egin 21-2-96 (14). 
en alguna ocasión como una fase del proceso hacia el autogobierno y las libertades, lo que apoyaría la interpretación progresiva y lineal de autonomía, autogobierno e independencia. Precisamente, lo que se echaba en cara al PNV era que había privado al Estatuto de su sentido original y que su política había conducido «a un parón total en la evolución de las libertades de todos los vascos» ${ }^{209}$.

La defensa de la necesidad del desarrollo del Estatuto no impidió que Oliveri afirmase que el Estatuto había dejado de ser «ilusionante» para los vascos, ya que el «estatalismo político cree más en él como instrumento de freno hacia la insaciabilidad nacionalista que para construir el país» ${ }^{210}$.

El mismo Oliveri en rueda de prensa posterior se explayó sobre el tema. El Estatuto estaba devaluado no sólo por las competencias que faltaban, sino también porque había «supuesto un proceso de desmoralización para la sociedad vasca». El Estatuto fue válido en su momento - y un acierto que había permitido tener instituciones propias-, porque no se pudo alcanzar otro y porque se interpretó en la dirección del autogobierno y de la relación bilateral con el Estado «para nuevos pactos que posibilitaran el desarrollo mayor del autogobierno». La revitalización del Estatuto exigía culminar las transferencias y revisar las leyes de bases que lo reducían. Por otra parte, el Estatuto había dejado der ser un «referente» para la sociedad vasca $-\mathrm{y}$ «cuando un instrumento político deja de ser un referente para la sociedad, deja de ser válido»-, lo que obligaba a buscar un nuevo consenso, que permitiese la integración de todos aquellos, que no creían en la vía estatutaria, incluidos los de Herri Batasuna, y que excluyese a aquéllos, cuyo proyecto político - como era el caso del PP - no contemplaba a «Euskadi como una comunidad diferenciada», lo cual haría difícil entender que el autogobierno era «un instrumento para el desarrollo integral de un país» ${ }^{211}$.

En un foro navarro como el de Tafalla, el Presidente de EA defendió que Euskadi y Navarra eran «miembros de una misma comunidad natural, con lazos culturales y sociales e intereses legítimos compartidos». La condición vasca de tal comunidad le llevaba a rechazar que los navarros «seamos expropiados de nuestra condición de vascos». Las posturas contradictorias sobre la fusión entre Euskadi y Navarra no debían impedir ni el establecimiento de «vínculos especiales» entre ambas, ni su progresivo

209 El Correo 24-2-96 (19).

210 Egin 21-2-96 (14).

211 El Mundo del País Vasco 1-3-96 (13). Parecidas declaraciones las de Lasagabaster en Egin 21-2-96 (15), en las que se añade: «Quizás sea un poco ingenua, pero estamos mejor que en otras épocas de la historia». 
acercamiento, respetando «la voluntad democrática de la mayoría de los ciudadanos navarros». La razón, que explicaba en parte la «pérdida de la conciencia colectiva» - ha de suponerse que se trataba de la pérdida de la conciencia colectiva de pertenencia a la comunidad natural vasca o, en otros términos no utilizados por razones evidentes, a la nación vasca-, era la desaparición del euskera de amplias zonas de la geografía navarra. La recuperación, por tanto, de las señas de identidad comunes a Navarra y Euskadi era, necesariamente, objetivo de los nacionalistas. La petición nacionalista del voto de los navarros se trató de fortalecer con los argumentos de la democracia, tal como se ha visto, y de la responsabilidad, que EA fundamentaba en su presencia institucional en el Gobierno de coalición de Navarra y en veinte alcaldías ${ }^{212}$.

Por ultimo, la afirmación, tal vez, más nacionalista de la campaña de EA se hizo a propósito de defender la unidad del nacionalismo. Este era necesario, porque en el futuro podría darse en Euskadi una división entre «nacionalistas y contranacionalistas» en sustitución de la que existía entonces entre «demócratas frente a violentos» ${ }^{213}$. No hay que olvidar que el Presidente del Partido había hablado de que existía un cierto desánimo nacionalista, consecuencia de la actuación de los dirigentes políticos ${ }^{214}$.

\section{Los contenidos o argumentos no nacionalistas}

La importancia dada al tema de la paz fue de tal extensión que alcanzó el 32,85\% de la identidad de partido, es decir, un 14,97\% del total de la campaña. Si a ello se suma la condena de ETA y Herri Batasuna por la práctica o defensa de la violencia, los tantos por cientos se duplican. Esto, más lo escrito anteriormente, ayuda a entender que la campaña de Eusko Alkartasuna se centrase, positivamente, en la defensa del nacionalismo y de la paz, y, negativamente, en la crítica tanto del PNV, por considerar que practicaba una política ajena a las tesis nacionalistas, como de Herri Batasuna y ETA, por su estrategia violenta, contraria al respeto debido a la dignidad de la persona y a la credibilidad del nacionalismo. En este último sentido se manifestaron Oliveri y Pilar Rahola, diciendo el primero que la «violencia de ETA está impidiendo a muchos vascos sumarse al nacionalismo, porque lo asocian a asesinatos, barbarie y secuestros» y la segunda que ETA contaminaba «la causa de las naciones libres» ${ }^{215}$.

\footnotetext{
212 El Correo 24-2-96 (19).

213 El Correo 25-2-96 (33).

214 Ver El Mundo del País Vasco 29-2-96 (12).

215 El Correo 26-2-96 (20).
} 
La tesis de que la persona es un valor absoluto por encima de cualquier objetivo político y de cualquier ideología fue el punto de partida de todo el tratamiento dado a las cuestiones de la violencia, de la paz, del terrorismo y de la reconcialiación ${ }^{216}$. No obstante, ya en la misma apertura de la campaña se habló de objetivos para la siguiente legislatura indicándose que el prioritario era la «reconciliación y la pacificación de nuestro pueblo, porque sin paz» no había más futuro que el del sufrimiento y miseria. Garaikoetxea insitió en que en Euskadi se vivía «rodeados del sufrimiento de los que han padecido el azote de la violencia» ${ }^{217}$.

El mismo político repitió al día siguiente, cuando fue agredido en Mondragón por radicales, su tesis de que sin paz el País Vasco carecía de futuro, «porque la violencia degrada nuestra convivencia, nuestra cultura y nuestra economía» ${ }^{218}$. La normalización tenía para EA, tal como se añadió, prioridad sobre la autodeterminación — afirmación no exenta de contradicciones-, al menos, para los cuatro años siguientes. Esto parecía querer decir que para ese tiempo la autodeterminación no era considerada como un instrumento para superar la violencia o, simplemente, que no había condiciones reales ni para aplicarla, ni para defenderla teóricamente como solución inmediata de la violencia, aunque todo ello se contradice con intervenciones posteriores. Sin embargo - ha de entenderse que a medio o largo plazo-, la pacificación dependía de la aceptación de las posturas mayoritarias de la sociedad vasca «por parte de quienes rechazan las instituciones autonómicas y de quienes niegan a los ciudadanos la posibilidad de determinar su futuro» ${ }^{219}$. Según esto, la sociedad vasca sería mayoritariamente favorable al Estatuto, en primer lugar, y, en segundo lugar, a la autodeterminación, siendo Herri Batasuna la que negaría la validez del primero y los partidos de ámbito general los que no admitirían que los ciudadanos vascos determinasen su futuro, es decir, se autodeterminasen. De este modo, si bien, de momento, la pacificación precedía en preferencia a la autodeterminación, en el futuro la autodeterminación sería la solución para la convivencia pacífica, una vez pasado el tiempo de validez del Estatuto de Autonomía.

Entre el «ahora» del Estatuto y el «después» de la autodeterminación estaba el diálogo «como primer paso que permita la tregua y el fin de la violencia $^{220}$.

216 Ver El Correo 17-2-96 (24) y 25-2-96 (33) entre otros.

217 El Correo 16-2-96 (24). Ver, también, El Correo 25-2-96 (33) y El Mundo del País Vasco 25-2-96 (25: la paz, primer objetivo; rechazo de la identificación del nacionalismo con la violencia).

218 El Correo 17-2-96 (24).

219 El Correo 17-2-96 (24).

220 El Correo 19-2-96 (21). Ver, también, El Correo 25-2-96 (36). 
La defensa del diálogo y de la negociación para la paz se convirtió en un tema muy recurrido en el resto de la campaña. La responsabilidad de llevar adelante el diálogo y la negociación correspondía al Gobierno central, según explicó J. Iraragorri, pero tanto el Gobierno navarro como el vasco tenían toda la legitimidad para «impulsar» el proceso y exigir al Gobierno central una posición distinta a la del momento, habida cuenta de la incapacidad de la Mesa de Ajuria Enea para liderar el proceso de paz $^{221}$. EA confesó que ya había dado pasos en tal sentido ante los Gobiernos autonómicos citados. Esta era la parte política del plan. Desde el punto de vista social y, a la vista de la necesidad, pero, a su vez, insuficiencia de las actuaciones policiales contra la violencia de ETA, hacía falta crear ámbitos o plataformas de reconciliación, donde estuviesen presentes todos los sectores sociales. Ello podía permitir alcanzar un amplio consenso social. A todo ello había que añadir la necesidad de que ETA y HB diesen señales de aceptación de una salida civilizada al conflicto, lo que, por el momento, no ocurría, ya que «el endurecimiento en la estrategia del MLNV (suponía) una grave involución» con respecto a momentos anteriores, en los que se había llegado a decir que las organizaciones armadas jamás debían interferir en los debates políticos ${ }^{222}$.

Esta exposición del programa electoral de EA sobre violencia y pacificación fue completada con algunas matizaciones hechas por Garaikoetxea. El diálogo con ETA no podía identificarse con cualquier diálogo. El diálogo debía ser serio, sin frivolidades y sin utilizaciones partidistas. Y la seriedad la daban las garantías. «No se puede dialogar a la sopa boba y sin garantías». En este sentido, ni las circunstancias de escalada terrorista, ni la inexistencia de voluntad real en los violentos para iniciar el «diálogo que parecen exigir» propiciaban las condiciones adecuadas. En tal caso, se podría llevar el burro al agua, pero no se podría hacerle beber, comentó el Presidente de EA. Las premisas «insoslayables» del diálogo eran el respeto a los derechos humanos y el respeto a la voluntad mayoritaria del pueblo vasco, que apostaba «por la libertad de defender democráticamente su derecho de autodeterminación». Con palabras textuales,

221 En otra ocasión J. Irarragorri manifestó: «Es muy difícil una respuesta común de los partidos a la violencia, y la pacificación no vendrá de la mano de la Mesa de Ajuria Enea. Fue un foro que sirvió para una cosa: decir que una serie de partidos está contra la violencia. Pero esto no supone que estemos de acuerdo en la solucion del problema. EA tiene bien claro que hay que iniciar ya una vía de diálogo» (El Correo 25-2-96 (36)). En defensa del diálogo y de la negociación ver, además de otros lugares citados, Deia 20-2-96 (7) y 23-2-96 (9); Egin 20-2-96 (14); El Mundo del País Vasco 25-2-96 (25) y 28-2-96 (14). En Egin 21-2-96 (15) se distingue entre diálogo-contacto y diálogo-negociación, cuya frontera no era muy segura según Garaikoetxea (ver El Mundo del País Vasco 28-2-96 (14)).

222 El Correo 23-2-96 (28). 
en el mitin central en Donosti, aunque en este caso no estaban referidas a las condiciones del diálogo, Garaikoetxea afirmó que sería «difícil que se asiente en Euskadi una paz justa, auténtica y verdadera, si no pasa por el respeto a la dignidad de las personas, por encima de todo» y a «la voluntad soberana del pueblo vasco». En parecidos términos, que recuerdan, una vez más, el principio absoluto de la dignidad de la persona, se sostuvo que la solución de la violencia exigía «el respeto a los derechos humanos, en toda circustancia» y «a la voluntad mayoritaria del pueblo vasco» ${ }^{223}$. E1 proyecto de EA, que se defendería con el mismo lenguaje en todos los foros 224 , contaba, se decía, con la adhesión de miembros históricos del MLNV225.

En otra ocasión Garaikoetxea puntualizó otra de las condiciones para el diálogo y la posible ulterior negociación con ETA en los siguientes términos: «Diálogo sí, negociación si llega el caso, pero siempre que se pueda verificar la seriedad de la intencionalidad de los interlocutores. Que no sea una maniobra táctica por parte de ETA y del MLNV para jugar con la negociación como un señuelo en el que otros nacionalistas, animados por ideales compartidos de defensa de las libertades del pueblo vasco, creemos una nueva correlación de fuerzas, se rompan las hoy establecidas y una vez que los nacionalistas estemos metidos en ese bloque negociador en favor de objetivos comunes, interrumpir la negociación y volver desde otras circunstancias totalmente diferentes de sensibilización social, de rupturas de bloques, a la estrategia propia del MLNV»226.

La necesidad del diálogo venía exigida por el origen político de la violencia. "Yo culpo - manifestó en una entrevista Irarragorri- a los partidos que han estado en el poder de no haber abierto el camino. No han querido escuchar, ni siquiera aceptar (sic) el origen político del problema. Si a una enfermedad tan grave como es la violencia, que padecemos hace 37 años, no la atacas de raíz, con medidas policiales sólo no se podrá solucionar. A la gente le han querido vender muchas veces que

223 El Correo 26-2-96 (20).

${ }^{224}$ Eusko Alkartasuna, dijo Garaikoetxea en otra ocasión, «será la voz que contribuya al proceso de pacificación y reconciliación de este país, y el que diga en Madrid la verdad de lo que sucede en Euskadi, sin dar versiones frívolas ni oportunistas» (El Correo 26-2-96 (20)).

225 El Correo 25-2-96 (33).

226 El Mundo del País Vasco 28-2-96 (14), donde también se afirma que el legitimado para dialogar y, en su caso, negociar era Herri Batasuna, el brazo político de ETA, aunque Garaikoetxea puntualizaba lo siguiente: «Yo desafío a que me digan con sinceridad si el brazo político estuviera contaminado por alguna presencia del brazo no político, si alguien rehusaría a hablar en unas conversaciones definitivas en términos que implicara alguna negociación; también desafío a que alguien me delimite claramente la frontera que hay entre lo que es negociación y lo que es diálogo». 
ETA estaba desapareciendo, pero sigue matando. Quiero que mejoren las medidas policiales, porque hasta ahora no han sido muy eficaces, pero la solución vendrá por el diálogo. Será difícil, duro, no sabemos si dará paso a una negociación, pero no se puede seguir engañando a la gente» ${ }^{227}$.

La paz buscada era «la llave para lograr la construcción nacional vasca». Sin ella no se podía «avanzar en el autogobierno ni crear un espacio económico propio», manifestó Oliveri ${ }^{228}$. La libertad de Euskadi incluía a «ciudadanos libres» 229 .

El respeto a los derechos humanos y la defensa de «las libertades nacionales del pueblo vasco por caminos pacíficos y democráticos ${ }^{230}$ establecían la «doble base» hacia la pacificación por la vía del diálogo. En manos del electorado quedaba la opción de «ir hacia la paz o adentrarse en la espiral de violencia» ${ }^{231}$.

La identidad pacífica de EA se extendía a campos como la insumisión o el servicio militar, sobre los que se pedía su despenalización y su abolición respectivamente ${ }^{232}$.

Otras cuestiones recogidas en el programa del Partido tuvieron poco realce en la campaña. Así ocurrió con el tema de la juventud vasca, que sufría «una imagen distorsionada» ${ }^{233}$, o con la mujer, en cuya incorporación a las listas electorales EA se consideraba pionera ${ }^{234}$.

La presentación de Eusko Alkartasuna como partido sin corrupciones también se hizo en clara búsqueda del contraste con los Partidos en el poder. Garaikoetxea lo dijo: «Asumimos nuestros errores, pero también queremos proclamar que nuestra trayectoria, en una época en la que han proliferado escándalos de todo tipo, es totalmente limpia» 235 .

Unicamente lo relativo a las cuestiones económicas y sociales tuvo alguna cierta relevancia, pero no tanto como daban a entender las declaraciones de Garaikoetxea, quien resaltó que la mayor parte de su programa electoral se dedicaba a proponer soluciones a los problemas económicos y sociales $^{236}$. En la campaña no se insistió en tales cuestiones, aunque se

227 Ver El Correo 25-2-96 (36). En El Correo 26-2-96 (20) Garaikoetxea criticó a los que durante quince años habían lanzado «un mensaje oportunista y gratificante al oído de los ciudadanos diciendo que la violencia estaba dando sus últimas bocanadas».

228 El Correo 26-2-96 (20).

229 Ibidem.

230 El Correo 26-2-96 (20).

231 El Correo 1-3-96 (25).

232 Ver El Correo 19-2-96 (21), Deia 19-2-96 (5) y Egin 19-2-96 (13).

${ }^{233}$ El Correo 18-2-96 (39).

234 El Correo 25-2-96 (36).

235 El Correo 29-2-96 (25). Sobre la regeneración de la vida política, ver Deia 20-2-96 (7).

236 Ver El Correo 17-2-96 (24). 
defendió la identidad de EA como Partido de inspiración socialdemócrata y progresista ${ }^{237}$ propugnando el fortalecimiento de políticas de empleo 238 o el Estado de Bienestar, sobre el que Irarragorri hizo algunas precisiones: «Las cotas del Estado de Bienestar alcanzadas — dijo- hay que mantenerlas y mejorarlas. Pero no puede entenderse como una vaca lechera que alimenta todo. Son necesarias algunas reformas para mantener esos logros. Hay que impulsar el ahorro del gasto público en capítulos que no redundan en beneficio de los ciudadanos y establecer alicientes a la iniciativa privada, con medidas fiscales a las empresas para generar empleo (...) Me parece una irresponsabilidad que algunos partidos digan no sólo que se van a mantener (las pensiones), sino que las van a subir. Hasta ahora ha habido proteccionismo y nos hemos acostumbrado a la sanidad gratuita, las pensiones, las ayudas contra la pobreza. La Administración tiene que espabilar y fomentar la iniciativa privada. Hay una experiencia en Gran Bretaña en la que no se paga seguro de desempleo, porque mucha gente se acostumbra a vivir justito, pero a vivir. Y allí lo que hacen es pagar a las empresas por contratar a los desempleados» ${ }^{239}$.

No faltó en el campo económico la tesis reiterada de que una de las razones que dificultaba el empleo, las inversiones y la creación de un espacio económico propio era la violencia ${ }^{240}$.

B) La crítica a los Partidos Políticos

\section{El Partido Nacionalista Vasco}

Más de una quinta parte de la campaña, tal como se ha recogido en los datos iniciales, la acaparó la crítica al Partido Nacionalista, con quien Eusko Alkartasuna disputaba el mismo espacio electoral. Las acusaciones giraron en torno al nacionalismo, la ambigüedad y el Partido único, con los corolarios correspondientes de voto útil y pactos entre ambos Partidos.

Tácita o expresamente se dijo que el PNV ocultaba o enmascaraba en la campaña reivindicaciones nacionalistas como la autodeterminación

237 Ver El Correo 16-2-96 (24). Ver también El Mundo del País Vasco 28-2-96 (15 y 16). En Deia 20-2-96 (7) Pello Yaben desarrolla la política económica de EA en materia de lucha contra el paro, reforma del mercado laboral y política de integración social. Ver también Egin 20-2-96 (14). Ver también en El Mundo del País Vasco 28-2-96 (15 y 16) entrevista a Garaikoextea.

238 Ver El Correo 24-2-96 (19).

239 Ver El Correo 25-2-96 (36).

240 Ver El Correo 18-2-96 (39), 24-2-96 (19), 26-2-96 (20). Sobre la euskaldunización ver El Mundo del País Vasco 28-2-96 (16); Garaikoetxea tenía «una cierta visión trágica de la situación» del euskera. 
por temor a «la erosión del electorado», buscando con ello el voto útil ${ }^{241}$. «Algunos - manifestó I. Martínez de Luna- renuncian a sus señas de identidad por considerarlas un mal cartel electoral...» ${ }^{242}$. La marginación electoral de la autodeterminación o la independencia y su reconocimiento en determinadas celebraciones daba un tinte oportunista al nacionalismo jeltzale ${ }^{243}$. Estas acusaciones expresadas al comienzo de la campaña se repitieron a su término, cuando Garaikoetxea dijo: «Los peneuvistas modulan el lenguaje en función de la oportunidad política». Así, radicalizaban su mensaje nacionalista, cuando tenían interés en acercarse a EA, «pero, a continuación, como se ha demostrado en esta campaña, rehúyen mencionar la autodeterminación o la independencia». El PNV sólo hablaba de «nacionalismo por oportunismo dos veces al año, durante el Alderdi y el Aberri Eguna. El PNV sólo nos tendrá a su lado cuando hoy diga una cosa y mañana la mantenga» ${ }^{244}$.

A esta oportunista ocultación del nacionalismo se sumaba el bloqueo del Estatuto Vasco. El PNV habría llevado el proceso autonómico «a un vaciamiento del sentido original del estatuto (y) a un parón total en la evolución de las libertades de todos los vascos». A la crítica acompañaba la petición de cambios «en sus aspiraciones de autogobierno, progreso y libertad» $»^{245}$.

En realidad, el comportamiento en materia nacionalista del PNV podía interpretarse como un aspecto más de su calculada ambigüedad, que tendría dos fases, la electoral, en la que se prescindiría del argumento nacionalista para captar el voto no nacionalista, y la de Legislatura, en la que se prescindiría hasta de la ética con el fin de satisfacer intereses de Partido y clientela.

A esta segunda fase pertenecían las contradicciones entre considerar prioritaria la reducción del paro y haber apoyado durante muchos años al gobierno central ${ }^{246}$ o pedir a EA una acción común en las Cortes y haber apoyado la Ley Corcuera o el cambio de actitud con el problema de los $\mathrm{GAL}^{247}$. «¿Qué clase de anteojos necesita Arzalluz —manifestó Garaikoetxea en relación a su papel de ambigüedad - cuando hace ya diez años nosotros ya denunciábamos los GAL» ${ }^{248}$.

241 El Correo 16-2-96 (24).

${ }^{242}$ El Correo 27-2-96 (23). Tal afirmación parecía referirse especialmente a la campaña del PNV en Araba y Bizkaia. Ver El Mundo del País Vasco 27-2-96 (16).

243 Ver El Correo 17-2-96 (24).

244 El Correo 2-3-96 (22).

245 El Correo 24-2-96 (19).

246 Ver El Correo 17-2-96 (24).

247 Ver El Correo 19-2-96 (21).

248 El Correo 19-2-96 (21). Ver El Mundo del País Vasco 19-2-96 (15). 
La acusación de «doble lenguaje», que repetidamente se hizo, no sólo se entendía en sentido literal, sino también como contradicción entre palabras y hechos (ideas y praxis) o utilización de estrategias o conductas contradictorias ante un mismo problema. Estas incoherencias intencionadas se manifestaban en las distintas posturas ante las comisiones de investigación sobre los GAL, en la oposición a la investigación de los fondos reservados, en la estrategia con Herri Batasuna, estrategia de «contradicción permanente» entre el aislamiento y los «acuerdos inconfesables, como el de la autovía de Leizarán» ${ }^{249}$, o en la búsqueda del voto conservador en Bizkaia o de HB en Gipuzkoa, y se habrían de consumar en la alianza del PNV con el vencedor de las elecciones, fuese cual fuese, ya que «así garantiza la continuidad de pactos inconfesables, así se tapan escándalos mutuos» ${ }^{250}$.

En unos casos los votos y en otros las alianzas interesadas, como el apoyo al PSOE en la anterior legislatura que le había permitido al PNV aparecer como el único representante de los vascos en los medios de comunicación — «han logrado el monopolio informativo a cambio de silenciar a otros nacionalistas», dijo Garaikoetxea-, eran la explicación del «doble lenguaje» del $\mathrm{PNV}^{251}$, «un mensaje sin futuro, porque llevan 20 años diciendo las mismas cosas acomodados en sus escaños» 252 .

Probablemente lo que menos se soportaba en Eusko Alkartasuna era la pretensión peneuvista de ser la única representación de los vascos y la identificación de Euskadi con el PNV o del jeltzale con el vasco. Así se criticó, con ocasión de la petición del voto útil, el interés por ser los «representantes únicos de los ciudadanos vascos en Madrid» ${ }^{253}$ y se denunció el pago recibido del PSOE por apoyos parlamentarios consistente en aparecer en los medios de comunicación como el único representante de los vascos, silenciando a otros nacionalistas ${ }^{254}$.

La pretensión de concentrar el voto nacionalista en los candidatos del PNV fue interpretado como una nueva revelación del «afán totalitario del partido de Xabier Arzalluz» ${ }^{255}$, tanto más injustificable cuanto que existía el miedo en las filas del PNV de que en las elecciones del 3

249 El Correo 1-3-96 (25).

250 El Correo 27-2-96 (23).

251 Ver El Correo 17-2-96 (24), 19-2-96 (21), 22-2-96 (27), 26-2-96 (20), 27-2-96 (23), 28-2-96 (24), 1-3-96 (25) y 2-3-96 (22).

252 El Correo 24-2-96 (19).

253 El Correo 24-2-96 (19).

254 El Correo 27-2-96 (23).

255 El Correo 28-2-96 (24). La defensa del pluralismo nacionalista la realiza Garaikoetxea en El Mundo del País Vasco 28-2-96 (16). 
de marzo su partido quedara reducido a «un partido exclusivamente "bizkaitarra" ${ }^{256}$. El PNV justificaba la concentración del voto en la necesidad de frenar al Partido Popular y a Herri Batasuna. Esto mereció la identificación del PNV con Herri Batasuna por su común «pretensión de convertirse en partido único en Euskadi». Ambas organizaciones aspiraban a representar en solitario al pueblo vasco. «Por eso - comentó Garaikoetxea-, cuando se sienten agredidos responden que la agresión afecta a todos los ciudadanos» ${ }^{257}$. Por otra parte, el apoyo prestado al Partido Socialista convertía el voto al PNV en el «más inútil que ha habido en las dos últimas legislaturas» ${ }^{258}$ y en un «insulto a la inteligencia de los electores vascos» 259 . Por lo que se refería a EA y el PNV los electores tendrían que elegir entre el voto al PNV «y sus apoyos al Gobierno central»o «los procedimientos democráticos y pacíficos de $\mathrm{EA}{ }^{260}$.

Las duras críticas emitidas contra el PNV por su actitud ante la Ley Corcuera, ante los fondos reservados, ante el GAL o ante el nacionalismo parecían concluir que si no se producía un cambio radical en sus planteamientos, tal como se pidió en alguna ocasión ${ }^{261}$, sería imposible toda colaboración entre ambos a lo largo de la legislatura, colaboración que según la prensa se había pedido desde el PNV. Así fue la primera conclusión establecida. «No podemos tener una voz, tenemos que tener dos voces a la fuerza porque disentimos en (sic) esa manera que tienen de ocultar los objetivos nacionalistas en campaña electoral, refugiándose en excusas económicas. Disentimos en la gestión económica y en la política industrial que se ha llevado a cabo... Ojalá pudiéramos tener una sola voz en los momentos críticos para el desarrollo político, económico y social de este país con estos caballeros» ${ }^{262}$. La misma conclusión se repitió en otra ocasión, invocando las razones ya sabidas ${ }^{263}$.

Pero también se afirmó que aún había espacio para la colaboración. Cuando así se dijo, se pidió a los parlamentarios del PNV que defendiesen «juntos el derecho de autodeterminación» ${ }^{264}$.

No había que olvidar, para concluir, la «tentación hegemónica» del PNV, que, en opinión de EA haría más difícil aún la colaboración de los

256 El Correo 28-2-96 (24). Según Irarragorri, a quien pertenecen las palabras entrecomilladas, tal miedo explicaba la obsesión jeltzale por ganar en Guipúzcoa.

257 El Correo 28-2-96 (24).

258 El Correo 28-2-96 (24).

259 El Correo 24-2-96 (19).

${ }^{260}$ El Correo 1-3-96 (25).

261 Ver El Correo 24-2-96 (19).

262 El Correo 23-2-96 (28). Ver también El Mundo del País Vasco 23-2-96 (9).

263 Ver El Correo 25-2-96 (36).

${ }^{264}$ El Correo 27-2-96 (23). Ver también El Mundo del País Vasco 27-2-96 (16). 
parlamentarios de ambos partidos en las futuras Cortes 265 . La colaboración sería posible en puntos de coincidencia «sobre la base del respeto mutuo, de la buena fe y del abandono de estas prácticas de corrupción de tránsfugas y de cosas por el estilo» ${ }^{266}$.

\section{Herri Batasuna}

A Herri Batasuna, que recibió una atención del 34,37\% de este apartado, es decir, un $18,71 \%$ del total de la campaña, y a todo el conglomerado de MLNV, ETA y Jarrai, se les llamó claramente fascistas. EA manifestó haber sufrido sus comportamientos violentos, frente a los que había opuesto la firmeza en el respeto a todas las ideas ${ }^{267}$. La vulneración sistemática de los derechos fundamentales de las personas mediante la violencia fascista ${ }^{268}$ — «no respetan los derechos humanos quienes mantienen a José María Aldaia y a José Antonio Ortega Lara torturados durante tanto tiempo» ${ }^{269}$-, mostraba la incompatibilidad entre patria y violencia. No se podía reclamar una patria a la vez que se sometía «a tormento» a un ciudadano, porque «cuando se conculca la dignidad de los individuos en aras de una patria se imita a Hitler, Mussolini y Franco» ${ }^{270}$. Tampoco se podía conciliar la libertad de un pueblo con la negación de las libertades individuales o con la negación de la democracia popular, porque «¿qué concepto de las libertades colectivas de un pueblo puede tener quien no respeta la emanación de la voluntad popular que cristaliza en unas instituciones? (...) Estos, que nos esperan a la salida de los mítines para insultarnos y tirarnos naranjas limoneras, pregonan ser los estandartes liberadores de nuestro pueblo» ${ }^{271}$.

La estrategia violenta de ETA fue calificada de «macabra» ${ }^{272}$ y el comportamiento de HB como semejante al de Franco ${ }^{273}$. Las bombas de ETA y, en concreto, las que estallaron en La Rioja durante la campaña, servían para «quitar una vez más la máscara de su "alternativa

265 Ver El Correo 28-2-96 (24). Sobre la dificultad de entendimiento con el PNV ver El Mundo del País Vasco 28-2-96 (14).

${ }^{266}$ Egin 28-2-96 (13). Ver también Deia 28-2-96 (7) y El Mundo del País Vasco 28-2-96 (16), que contienen, además, las críticas ya conocidas contra el PNV.

267 Ver El Correo 18-2-96 (39).

268 «Cuando defendemos, declaró Garaikoetxea a la clientela radical, los derechos humanos o la dignidad de las personas, no estamos haciendo pactos antiabertzales» (El Correo 19-2-96 (21)). Ver también Deia 19-2-96 (5).

269 El Correo 26-2-96 (20).

270 El Correo 2-3-96 (22).

271 El Correo 19-2-96 (21). Ver El Mundo del País Vasco 19-2-96 (15).

272 El Correo 16-2-96 (24).

273 Ver El Correo 19-2-96 (21) y Deia 19-2-96 (15). 
democrática" 274 . En lugar de incorporarse al nacionalismo pacífico y democrático Herri Batasuna radicalizaba y endurecía sus posturas y se dedicaba al puro testimonialismo de calle ${ }^{275}$.

La amnistía que se exigía en la alternativa de ETA mereció este comentario del Presidente del Partido: «A mí me parece que esto de la amnistía como paso previo para conseguir una tregua, mientras se está desarrollando una lucha armada o una guerra que se pretende tenga connotaciones de tal, implica una cierta contradicción. Creo que en la propuesta de ETA, como en otras ocasiones, hay una especie de petición de principio cuando se empieza por el final dando por supuesto que hay que conceder lo que se pretende conseguir y lo que son modestas condiciones previas parece que son los objetivos que un poco menos resumidos estaban en la alternativa KAS» ${ }^{276}$.

Clara fue la definición de HB-ETA como fascismo y clara, también, fue la descalificación permanente de la estrategia violenta. Pero nada se repitió tanto como las nefastas consecuencias, que se derivaban de la política radical. Esta negaba toda posibilidad de $\mathrm{paz}^{277}$; dificultaba las inversiones extranjeras — «son difíciles de obtener mientras persista el terrorismo de ETA» ${ }^{278}$ —; ayudaba a explicar la crisis económica del País Vasco, que se debía «en buena parte, al clima de violencia y a la reputación ${ }^{279}$ que la misma nos ha deparado ante el inversor exterior» ${ }^{280}$; era «uno de los peores enemigos del verdadero nacionalismo vasco, que nada (tenía) que ver con la violencia» ${ }^{281}$; impedía a «muchos vascos sumarse al nacionalismo, porque lo (asociaban) a asesinatos, barbarie y secuestros» ${ }^{282}$; alejaba a los ciudadanos del abertzalismo y de la democracia; perjudicaba la implantación del nacionalismo en Navarra; profundizaba la separación entre Navarra y la Comunidad Autónoma Vasca ${ }^{283}$; impedía el desarrollo del «proceso de emancipación nacional» ${ }^{284}$; contaminaba «la causa de las naciones libres» ${ }^{285}$; degradaba la convivencia, la cultura y la economía

274 El Correo 19-2-96 (21).

275 Ver El Correo 26-2-96 (20), 29-2-96 (25) y 1-3-96 (25).

276 El Mundo del País Vasco 28-2-96 (15).

277 En El Correo 1-3-96 (25) se acusa a H.B. y al PNV de «ensombrecer el camino hacia la paz».

278 El Correo 18-2-96 (39). En El Correo 24-2-96 (19) se dice que ahuyentaba las inversiones de Euskadi. Ver también Deia 18-2-96 (9) y Egin 19-2-96 (15).

279 «Imagen de incivilidad» se dice que daba la izquierda radical en El Correo 24-2-96 (19).

280 Ibidem.

281 El Correo 19-2-96 (21).

282 El Correo 26-2-96 (20).

283 Ver El Correo 24-2-96 (19).

284 El Correo 26-2-96 (20).

285 Ibidem. 
vascas $^{286}$; proporcionaba «adversarios al nacionalismo vasco»287; impedía la generación de empleo ${ }^{288}$ y distorsionaba la campaña electoral ${ }^{289}$.

Garaikoetxea resumió con estas palabras las negativas consecuencias de la estrategia violenta radical: «Nada ha sido tan nocivo y demoledor para la causa del nacionalismo vasco que el rupturismo asociado a ETA y Herri Batasuna» 290 .

Según esto, el voto a Herri Batasuna era un «voto perdido» ${ }^{291}$ para los intereses de los vascos, especialmente, de los nacionalistas, cuando, además, «un serio correctivo electoral es la única posibilidad que puede traernos la esperanza de que cambie su actitud» ${ }^{292}$.

En esta crítica general al MLNV hay que situar la apelación a la unidad del nacionalismo ante la posibilidad de que en el futuro la separación entre «nacionalistas y contranacionalistas» sustituyese a la separación de los «demócratas frente a los violentos» ${ }^{293}$, porque «cuando se proscriben los medios violentos y las vías ilegítimas, es necesario ser consecuentes y comprometerse con quienes defienden las libertades nacionales del pueblo vasco por caminos pacíficos y democráticos como hace EA» ${ }^{294}$. De momento, lo que parecían pretender los dirigentes radicales era provocar la espiral de violencia mediante el método «acción-represión-acción» ${ }^{295}$.

\section{Partido Socialista}

Poca atención recibió este Partido; únicamente el $8 \%$ de este apartado, es decir, el 4,39\% del total de la campaña. Se le acusó de impedir, juntamente con el Partido Popular y Herri Batasuna, el debate político electoral y de «obtener votos a cambio de promesas engañosas» ${ }^{296}$, tal como hacía, también, el Partido Popular. No era ajeno a los mensajes falsos e

286 El Correo 17-2-96 (24).

287 El Correo 27-2-96 (23).

288 Ver El Correo 27-2-96 (23).

289 «Quieren acaparar el sentir de la sociedad con su violencia», declaró Irarragorri en $E l$ Correo 25-2-96 (36).

${ }^{290}$ El Correo 24-2-96 (19). La violencia independendista ni debía crear miedo a defender libremente cualquier ideología ni debía «arrinconar y ocultar nuestras reivindicaciones legítimas por decir no a quienes, por un procedimiento ilegítimo, piden las mismas cosas» (El Correo 19-2-96 (21)).

291 El Correo 27-2-96 (23).

292 El Correo 1-3-96 (25).

293 El Correo 25-2-96 (33). Más críticas a HB en: El Mundo del País Vasco 21-2-96 (14) y 28-2-96 (15).

294 El Correo 26-2-96 (20).

295 Ver El Correo 1-3-96 (25).

${ }^{296}$ El Correo 24-2-96 (19). Ver, también, El Correo 25-2-96 (36). 
interesados, por razones electorales, de los últimos años sobre el final de la violencia y su petición de voto nacionalista para frenar el ascenso del PP mereció la calificación de «atentado al sentido común y a la inteligencia». Era una aspiración a «arañar votos en las bases nacionalistas mediante la manipulación y el engaño» ${ }^{297}$.

Enemigo del nacionalismo vasco, había chantajeado, como cualquier otro partido estatal, a Eusko Alkartasuna para «silenciarnos con acusaciones de dar pábulo a los violentos» ${ }^{298}$.

El Partido Socialista era uno de «los del otro lado», a los que Garaikoetxea pidió que no utilizasen la «coartada que, desgraciadamente, ofrece la violencia de este país, para pretender que todos los gatos sean pardos, que no existen más contradicciones nacionales en Euskadi, que no hay un contencioso político (...) Debemos acabar con esa idea que une el abertzalismo o nacionalismo con la violencia. Nosotros somos tan abertzales o más que ellos (los de H.B.)» ${ }^{299}$.

Euskadi debía al socialismo - «es igual que sea el PP o el PSOE el que gobierne en Madrid, ya que los ataques a Cataluña y Euskadi de los jacobinos socialistas o los de la caverna de siempre no son tan distintos» ${ }^{300}$ - el desmantelamiento industrial, el bloqueo del desarrollo del Estatuto y el intento de «relegar el euskera al cajón del olvido» ${ }^{301}$. El PSOE se había «manifestado siempre como un enemigo del nacionalismo vasco» ${ }^{302}$.

\section{Partido Popular}

La mayor parte de las acusaciones contra el Partido Popular fueron dichas, también, contra el Partido Socialista por aquello de que ambos eran del «otro lado» (estatalistas frente a nacionalistas), expresión que parecía dividir a los electores y ciudadanos vascos entre vascos y no vascos o entre nacionalistas y no nacionalistas, en clara contradicción con la principal separación entre demócratas y defensores de los derechos humanos, por un lado, y antidemócratas y violentos, por otro, que electoralmente, al menos, se defendía. Por ello, se da por supuesto cuanto de común se ha recogido anteriorrnente referido al PP y al PSOE.

297 El Correo 29-2-96 (25) y 26-2-96 (20). Sobre el uso electoralista de la violencia, acusación común contra el PSOE y el PP, ver El Mundo del País Vasco 23-2-96 (9).

298 El Correo 27-2-96 (23) y 29-2-96 (25).

${ }^{299}$ El Correo 19-2-96 (21). Ver también Egin 19-2-96 (13) y El Mundo del País Vasco 19-2-96 (15).

300 El Correo 26-2-96 (20).

301 El Correo 29-2-96 (25).

302 El Correo 29-2-96 (25). 
Como Aznar había dicho en Bilbao que primero «hay que ser demócrata antes que nacionalista», desde EA se le respondió que según tal criterio, como la democracia exigía respetar todas las ideas e, incluso, el derecho de autodeterminación, debía reconocer, en primer lugar, tal derecho, es decir, ser demócrata, y, después, ser nacionalista español. A pesar de la máxima electoralista se esperaba que el PP no admitiese el derecho de autodeterminación, porque «sigue empeñado en defender la trasnochada concepción de España como unidad de destino en lo universal y sigue ciego ante la realidad que supone la existencia de un problema vasco» ${ }^{303}$.

Acusado de hacer fracasar la comisión GAL y de utilizar una imagen tradicional -y por ello, electoralista - de la mujer, el PP fue tachado, además, de proponer como única política para Euskadi la del «tratamiento estrictamente policial del conflicto» que se vivía. Con ello el líder popular demostraba que seguía «sin enterarse (sic) que ni la policía de la dictadura, ni la de la democracia, ni el siniestro Gal, ni siquiera nuestra propia Ertzaintza han podido poner fin a la violencia que padecemos», según manifestó J. Irarragorri ${ }^{304}$. Un triunfo electoral del PP podría complicar todavía más la política en Euskadi. «Sólo nos falta — dijo Garaikoetxea en este sentido- un Gobierno que contribuya ciegamente a alimentar la espiral "acción-represión-acción", que parecen perseguir los dirigentes del MLMV» ${ }^{305}$.

\section{La campaña de Herri Batasuna}

\section{Datos básicos}

La información de la campaña de Herri Batasuna fue cuantitativamente inferior a la del PNV y EA, tal como se indicó en la introducción de este trabajo, donde se destaca que, tomando como base (100) la información sobre el PNV, la de Herri Batasuna únicamente llegó al 43,82. Esto no afectó a la objetividad de la información sobre la campaña y el Programa electoral de acuerdo con una análisis comparativo de la prensa utilizada.

El contenido de la campaña potenció mucho más la imagen o identidad de la coalición, dentro de la cual la prensa incluyó a todas las

303 El Correo 20-2-96 (15). Ver también Deia 20-2-96 (3); Egin 20-2-96 (12) y El País 20-2-96 (20). Críticas comunes al PSOE y PP en El Mundo del País Vasco 2-3-96 (11).

304 El Correo 20-2-96 (15).

305 El Correo 1-3-96 (25). 
agrupaciones del Movimiento de Liberación Nacional Vasco, incluida ETA, que los aspecto críticos, si bien éstos fueron inseparables de los primeros. La imagen de la coalición alcanzó el 79,22\% del total, frente al 20,78\% de la crítica de los Partidos Políticos, que mejor sería calificar de crítica de todo el sistema político.

En el apartado de identidad de HB el contenido nacionalista o la argumentación nacionalista en la petición del voto ocupó el 53,57\%, es decir, un $41,25 \%$ del total de la campaña. Los contenidos no estrictamente nacionalistas, pero determinados únicamente por la premisa nacional, como los presos, los secuestros, la estrategia de ETA o las soluciones a la violencia ocuparon el $32,31 \%$, es decir, el $24,88 \%$ del total. El $14,11 \%$ restante de la imagen, $10,86 \%$ de la campaña, se dedicó a la actitud postelectoral de HB, que no puede ser considerada ni de apoyo ni de oposición al Gobierno, sino de negación del sistema socio-político vigente.

La crítica a los Partidos Políticos fue una parte del rechazo general del sistema social y político, que llegó a la cota del 84,93\%, o sea, un $17,64 \%$ del total de la campaña. El Partido Nacionalista Vasco y Eusko Alkartasuna, como partidos nacionalistas, recibieron una breve y específica atención, que alcanzó el 15\%, es decir, el 3,11\% del total.

Participaron en la campaña Idígoras, Aoiz, I. Olalde, Olano, K. Rodríguez, Erkizia, Rufi Etxebarria, Joseba Alvarez y K. Landa. Unicamente cabe destacar por su extensión en esta actuación la de Aoiz y la de K. Rodríguez.

\section{El desarrollo de la campaña}

\section{A) La identidad o imagen de Herri Batasuna}

\section{El contenido nacionalista de la campaña}

La defensa e identificación con la independencia nacional vasca fue el núcleo más esencial y más extenso de toda la argumentación o propaganda en la petición del voto, independencia, que, si bien cualitativamente era separable de aquello de lo que se pretendía separar, es decir, España y Francia, textualmente y, sobre todo, argumentalmente era inseparable. La independencia fue casi el único argumento nacionalista utilizado, ya que, por ejemplo, la autodeterminación en cuanto instrumento y procedimiento para lograr aquélla no fue prácticamente citada. Esto induce a pensar, como ya se observó en otros trabajos ${ }^{306}$, que en el vocabulario radical la

306 Ver, por ejemplo, mi trabajo «Elecciones al Parlamento Vasco del 23 de octubre de 1994», en Estudios de Deusto, vol. 42/2, julio-diciembre 1994, pp. 63.64. 
autodeterminación se identifica con la independencia, con el fin, y no con el medio o instrumento, el ejercicio de la voluntad democrática de los ciudadanos. La Euskadi independiente se defendió, además, en la mayoría de los casos, sin ningún otro calificativo como, por el contrario, ocurrió cuando K. Landa dijo expresamente que el voto a HB abría «el camino a una Euskal Herria independiente y socialista» ${ }^{307}$. Pudo ser ésta la única ocasión en que se aludió al fin revolucionario del MLNV.

$\mathrm{La}$ independencia era una necesidad, por un lado, para garantizar la vida y la libertad del pueblo vasco y, por otro, para realizar el modelo adecuado de sociedad, que jamás se desarrolló. Así, en el acto de presentación del mitin de Anoeta del día 24, se dijo que HB quería llevar a la sociedad «la reivindicación y la exigencia de independencia, porque estamos convencidos de que Euskal Herria la necesita cada vez más (...) sin la independencia Euskal Herria no logrará ser un pueblo libre (...) todo pueblo que depende de alguien está condenado a morir, mucho más si quienes le dominan, son Estados tan agresivos, violentos y reaccionarios como el español y el francés ${ }^{308}$. Mediante la independencia se podría organizar la sociedad «de la manera correcta» y aplicar «nuestro modelo social, económico y político» ${ }^{309}$. El mitin multitudinario de Anoeta se entendía como «un reto en esta situación de agresión, en esta cruzada contra la izquierda abertzale en la que parece que todo vale para intentar hacer callar a HB y a las reivindicaciones políticas independentistas (...) [y como] un grito de independencia, que tendrán que oír los gobiernos de Madrid y París y del que tendrán que sacar conclusiones» ${ }^{310}$.

Las elecciones de marzo marcarían «la línea que separa a los españolistas de los que luchan por la independencia», manifestó Idígoras antes de ser detenido y apartado de la campaña. Lo mismo repetiría a través de un vídeo pocos días más tarde al afirmar que sólo había dos caminos: «Ser españolista y colaboracionista, o ser de la izquierda abertzale» ${ }^{311}$. Además, era culpa del Estado español haber situado a los vascos ante la

307 El Correo 2-3-96 (22). La independencia aparece en Egin 16-2-96 (3); Deia 16-2-96 (8); Egin 17-2-96 (11), 19-2-96 (11) y 27-2-96 (9); Deia 28-2-96 (7).

308 El Correo 17-2-96 (14). En Deia 17-2-96 (9) se dice que la independencia «permitirá que Euskal Herria tenga voz propia en Europa y en el mundo».

309 El Correo 17-2-96 (14). Ver también Egin 16-2-96 (3), 29-2-96 (9) y Deia 29-2-96 (6), donde tampoco se especifican las características del modelo social.

310 El Correo 17-2-96 (14). El término de «cruzada» lo utilizó Aoiz en bastantes ocasiones. La Ertzaintza fue acusada de participar en la represión de HB. Lo dijo Karlos Rodríguez: «La Ertzaintza no pierde oportunidad para insultar y apalear a nuestra gente» (El País 18-2-96 (19)).

311 El Correo 25-2-96 (34). En El Correo 27-2-96 (23) se afirma que en las elecciones no había más que dos elecciones: «Una apuesta por España y otra, Herri Batasuna, por Euskal Herria». 
necesidad de optar por el independentismo o por el españolismo, lo que hacía superflua la discusión sobre la participación institucional de HB. En su opinión, los candidatos de la coalición, presos de ETA, familiares de los mismos o víctimas de la guerra sucia, mostraban «el sufrimiento, la tortura y la represión del Estado contra el pueblo vasco, pero también la voluntad de seguir hasta lograr la independencia». Era imposible que Euskadi viviese más tiempo unida con España, ya que ésta impedía ejercitar «sus derechos». La orden de secuestro del vídeo de ETA, donde se exponía la alternativa de ésta, demostraba «la locura colectiva del Estado en un intento de reprimir al movimiento independentista» ${ }^{312}$.

En el mitin de Anoeta, el principal de la campaña, Aoiz, usando un lenguaje épico y heroico, además de inobjetivo, afirmó que la campaña estaba centrada en el «combate entre Euskal Herria y España» y que, por ello, los nacionalistas españoles y sus colaboracionistas (PNV y EA) habían «organizado la gran cruzada en contra del movimiento independentista con prohibición de vídeos, detenciones, registros o el encarcelamiento de Jon». A pesar de ello, tanto Madrid como París tendrían que oír que «nosotros queremos la independencia y tenemos el propósito de lograrla». La separación de España y Francia era «irremediable», porque Euskal Herria sufría su sometimiento y su represión. Pero si ambos pensaban detener a la izquierda abertzale, cometían una lamentable equivocación, fruto del desconocimiento de Euskal Herria y de la propia izquierda abertzale. "Quien quiera pruebas de eso, aquí la tiene, aquí mismo tiene hoy una hermosa prueba» ${ }^{313}$.

Aoiz ya había dicho al comienzo de la campaña que tal «cruzada» no iba «contra la violencia, ni contra la lucha armada. El problema no son

312 El Correo 19-2-96 (21). Ver también El Mundo del País Vasco 19-2-96 (5). En Deia 19-2-96 (5): HB no cederá ante la represión contra la izquierda abertzale. Egin 19-2-96 (11) amplía la intervención de Idígoras en Usurbil: «No podemos vivir ni un minuto más dentro de España...; ante el avance del independentismo vasco y la popularización de una "alternativa democrática" para superar la actual situación de conflicto, hay una locura colectiva en el Estado, que responde, como siempre lo ha hecho, con la represión, las amenazas y las coacciones; ...las últimas actuaciones del Gobierno y el Estado español contra Euskal Herria pretenden incluso la ilegalización del algo que está legitimado por los propios ciudadanos de este país...; éste no es el momento de discutir si instituciones sí o instituciones no, ya que, por encima de este debate, existe otro clarísismo, al que nos ha llevado el Estado español, que es el de independentismo o españolismo».

313 El Correo 25-2-96 (34). El mitin de Anoeta fue, además del acto central de la campaña, el argumento fundamental para legitimar los objetivos de HB; ver Egin 17-2-96 (11: presentación); Deia 25-2-96 (6); Egin 25-2-96 (9 y ss.); El País 25-2-96 (26); El Mundo del País Vasco 25-2-96 (30 y 31); Egin 23-96 (14: el mitin más multitudinario). El argumento de la cruzada y la represión contra la independencia se utilizó durante toda la campaña; ver Egin 16-2-96 (3); Deia 17-2-96 (9) y 28-2-96 (7); Egin 29-2-96 (13) y 2-3-96 (14: fracaso del Estado en la represión de HB). 
los medios, sino los objetivos. A lo que tienen miedo es al independentismo» ${ }^{314}$.

Erkizia dio por hecho que los vascos querían la autodeterminación y la independencia - lo había demostrado, según él, el mitin de Anoeta- y que sólo con su logro se colmarían «los deseos de los vascos». La democracia exigía que se reconociese al pueblo vasco semejante derecho $^{315}$.

El mitin de Anoeta había demostrado el «ansia» por la soberanía total, al que seguiría la lucha de Herri Batasuna por lograr la independencia «con todos los medios» ${ }^{316}$, porque, después de las elecciones, los grandes partidos debían saber que el conflicto vasco seguiría presente ${ }^{317}$.

Un comunicado de la Mesa Nacional insistió en los mismos objetivos. Los abertzales debían llenar «las urnas españolas (...) de votos independentistas (...) la independencia, además de un derecho, es una necesidad para que Euskal Herria sobreviva, para defender su cultura, su lengua y su economía y para construir una sociedad progresista y justa» ${ }^{318}$.

La intervención de K. Rodríguez a favor de la independencia unió la argumentación de que la dependencia de España y Francia era el origen de todos los males de la sociedad vasca con la reclamación de un sistema financiero, un marco de relaciones laborales y un espacio económico propios del País Vasco como «instrumentos fundamentales» para resolver los problemas y avanzar hacia la independencia. Estas declaraciones siguieron a una concentración de radicales ante diversas entidades bancarias, presidida por un pancarta con el lema de «el futuro de nuestra economía... la independencia» ${ }^{319}$.

Los trabajadores, por su parte, debían dar su voto a Herri Batasuna, porque, además de servir para manifestar «su rabia y su rebeldía», serviría, también, para fortalecer el proyecto independentista frente al «intolerante nacionalismo español» ${ }^{320}$.

314 Egin 16-2-96 (3). En Egin 20-2-96 (11) aparece una entrevista a Aoiz, en la que éste expone un resumen de todas sus aportaciones a la campaña: Nerviosismo e impotencia del Estado español ante la política abertzale; farsa de la democracia española; la ilegalización de HB: cosa de locos o fascistas; lo más grave era el rechazo de la «alternativa de ETA», la propuesta de solución del conflicto; ciertos medios de comunicación apoyaban también la oposición a la solución del conflicto; persecución del abertzalismo e incompatibilidad de España y Euskal Herria.
315 El Correo 26-2-96 (21).
316 El Correo 27-2-96 (23).
317 El Correo 27-2-96 (23).
318 El Correo 28-2-96 (23).
319 El Correo 29-2-96 (25).
320 El Correo 1-3-96 (25). 
La campaña se interpretó como un conflicto «entre Euskal Herria y el Estado», por lo que la alternativa entre el voto al Partido Popular o al PSOE era una «falsa opción». La alternativa electoral para los ciudadanos vascos era la que presentaba Herri Batasuna con su «sí a Euskal Herria, frente a la España impuesta». La campaña se había encargado de demostrar la falsedad de la primera y la validez de la segunda, ya que, según Aoiz, el proceso electoral había estado polarizado por el conflicto «entre Euskal Herria y el Estado» ${ }^{321}$.

\section{Otros contenidos o argumentos o contenidos programáticos no nacionalistas}

Difícilmente puede afirmarse que existiesen en la campaña de HB contenidos no determinados o definidos por el elemento nacional o nacionalista, pero, como en sí mismos considerados no eran necesariamente nacionalistas, tal como ocurría, por ejemplo, con las propuestas de pacificación, se analizan en esta sección, tal como se dijo más arriba.

La implantación del socialismo o la defensa de un sistema financiero, económico y laboral propio para Euskadi fueron temas de la campaña, pero se utilizaron de manera muy ocasional y en su vertiente negativa de rechazo del sistema social y político vigentes por imposición de Francia y España ${ }^{322}$. Aoiz, por ejemplo, defendió la transformación de las estructuras sociales y económicas - sin decir en qué consistían- junto con la defensa de la verdadera democracia y de la independencia para Euskal Herria a la vez que condenaba la pseudo-democracia española y denunciaba al Estado español como terrorista. «Quienes aspiramos a la independencia y a un profundo cambio social estamos en contra de las imposiciones y rechazamos esta pseudo-democracia española en la que existen presos políticos, en la que se tortura, en la que el Estado es terrorista y el mayor violador de los derechos humanos, y en la que se persigue a la gente por sus ideas políticas» ${ }^{323}$.

El apoyo a los presos de ETA y la petición de amnistía total se acompañó de su proclamación como los mejores en la lucha por la paz, la libertad y la vertebración de Euskadi ${ }^{324}$, a la vez que se afirmaba que para acabar con el problema de fondo que estaba detrás de los secuestros (Aldaia y Ortega Lara) había que aplicar soluciones políticas. La finalidad de los secuestros era, en general, financiera, si bien, otros, como el de

\footnotetext{
321 El Correo 2-3-96 (22).

322 Ver lugares ya citados: El Correo 29-2-96 (25) y 2-3-96 (22).

${ }^{323}$ Egin 16-2-96 (3). Ver, asimismo, Egin 29-2-96 (9) y Deia 29-2-96 (6).

324 El Correo 25-2-96 (34).
} 
Ortega Lara, no obedecían a esa finalidad, ya que «ETA — según manifestó K. Rodríguez, miembro de la Mesa Nacional de HB-, hace una reflexión sobre las cárceles españolas y los presos para enmarcar el secuestro, y recuerda al Gobierno español que tiene que cumplir su propia ley. Y hacía una reflexión en el sentido de que si el Gobierno cumpliera sus propias leyes, los funcionarios de prisiones dejarían de ser un objetivo estratégico. De ahí es difícil sacar conclusiones en cuanto al desenlace» ${ }^{325}$.

Fue la llamada alternativa democrática de ETA la propuesta más defendida en la campaña, si bien nunca se desveló en la prensa en qué consistía. Supuesto el conflicto de Euskal Herria con el Estado español, «un paso positivo hacia la resolución del mismo» estaba en el vídeo de ETA, manifestó Idígoras ${ }^{326}$. No afectaba al carácter «democrático» de semejante propuesta el hecho de proceder de una organización, que tenía a dos ciudadanos secuestrados y que presionaba sobre los ciudadanos con las armas, ya que «las ofertas o las alternativas adquieren su carácter democrático en función de los contenidos. Y hablando de presión de las armas, el patrimonio lo tiene la Ertzaintza, la Guardia Civil y la Policía Nacional. Sin embargo, eso no quita para que nosotros reconozcamos cualquier propuesta que pueda hacer el Estado y diremos si es democrática o no en función de sus contenidos» ${ }^{327}$. Dispuesto a definir lo que era democrático y después de negar que HB covocara a los boicoteadores y agresores de los mítines de otros Partidos - aunque en la concentración de HB en Bermeo sus simpatizantes repartieron hojas llamando a la lucha callejera-, como había ocurrido en Rentería y Mondragón, Rodríguez manifestaba que HB no condenaba ese tipo de acciones, porque de todos era conocida su posición «ante cualquier expresión que haya en Euskal Herria de denuncia de la falta de libertades, de dispersión de los presos (...) en ese contexto no condenamos» ${ }^{328}$.

La alternativa de ETA, a cuya difusión se comprometía algún dirigente de $\mathrm{LAB}^{329}$, era la solución del «conflicto vasco». La izquierda abertzale no quería prolongarlo, pero anunciaba que seguiría «adelante en su lucha» ${ }^{330}$. Se trataba de una oferta «en positivo» de la izquierda abertzale, la única propuesta durante la campaña. «Esto es muy grave,

325 El Correo 25-2-96 (19).

326 El Correo 19-2-96 (21). Sobre tal alternativa ver: Egin 21-2-96 (13: la Mesa Nacional la asume) y 27-2-96 (9); El Mundo del País Vasco 22-2-96 (20: HB la impulsará); El País 21-2-96 (13).

327 El Correo 26-2-96 (19); manifestaciones de K. Rodríguez.

328 El Correo 26-2-96 (19).

329 Ver El Correo 1-3-96 (25).

330 El Correo 27-2-96 (23). 
sobre todo teniendo en cuenta que se ha criminalizado - afirmó Aoizel intento de HB de dar a conocer esa única propuesta» ${ }^{331}$.

La importancia que se dio al resultado electoral fue enorme. Ya lo había dicho Aoiz en el mitin de Anoeta: «En su larga lucha, este pueblo jamás ha desechado una sola arma: nuestra arma para luchar en estas elecciones es el voto para fortalecer nuestro proyecto» ${ }^{332}$. Con palabras semejantes se insistió en la importancia del voto para el movimiento radical: «Nos importa muchísimo y estamos convencidos de que conseguir el mayor número de votos es un elemento muy importante para el fortalecimiento de la izquierda abertzale. No es el único elemento que demuestra la fortaleza de este proyecto, pero sí es una expresión clara y nítida de ese fortalecimiento y para nosotros es fundamental» ${ }^{333}$. El mismo comunicado de HB pedía llenar las urnas españolas de votos independentistas, para que el Estado tuviera que sentir «la fuerza y el clamor irreductible de nuestros votos», los únicos que podían hacer reflexionar al Estado y presionarle para que cambiara su «cerril intransigencia» ${ }^{334}$.

\section{Gobierno u oposición postelectoral. Continuismo en la estrategia de $H B$}

No puede quedar ninguna duda de que la actitud durante la siguiente Legislatura no podía estar ni con el Gobierno ni con la oposición, ya que lo uno o lo otro requería la aceptación del sistema político. No obstante, se incluye aquí la estrategia anunciada por HB, que preveía el continuismo en su línea de actuación. El «nada ni nadie va a condicionar la acción política» de $\mathrm{HB}$, dicho, en principio, en relación a la campaña, valía, también, para la siguiente Legislatura ${ }^{335}$. Se tomaría buena nota de los resultados electorales, pero los mismos no serían «un elemento determinante» de la estrategia futura ${ }^{336}$.

HB esperaba una «mayor represión» del próximo Gobierno, independientemente de quién fuera el Partido vencedor en las elecciones, pero la represión no cambiaría el sentido del enfrentamiento, sino que produciría

331 El Correo 2-3-96 (22).

332 El Correo 25-2-96 (34).

333 El Correo 26-2-96 (19).

334 El Correo 28-2-96 (23). La petición del voto aparece también en Deia 17-2-96 (9); Egin 19-2-96 (11: voto, pero sin asistir al Parlamento); Egin 28-2-96 (13: Gestoras piden el voto para HB); Deia 1-3-96 (8: LAB pide el voto); Egin 1-3-96 (10). El sentido del voto (lucha, independencia, amnistía, no a España y a la violencia del Estado español) aparece también en: Egin 18-2-96 (11); Deia 28-2-96 (7); Egin 29-2-96 (13: responder en las urnas y en la calle); Egin 1-3-96 (10); Egin 2-3-96 (14) y El Mundo del País Vasco 2-3-96.

335 El Correo 17-2-96 (14).

336 El Correo 26-2-96 (19). 
«el recrudecimiento y la intensificación» del mismo ${ }^{337}$. Estas palabras, que probablemente fueron las últimas de la campaña, completaban las declaraciones de K. Rodríguez, en las que se recogía la oferta política para la próxima Legislatura: «Salga el Gobierno que salga, tiene que reflexionar y aprender del PSOE, que en los últimos 14 años, con diez millones de votos, con la colaboración francesa y la represión policial no ha conseguido acabar con ETA. No vemos que el PP pueda tener más elementos que los que tuvo el PSOE en 1982 para pensar que puede aniquilar al movimiento independentista. Y, creo que hay que decirles, "señores, no tiren por la ventana otros 14 años, apostando por la vía represiva". Por otra parte, ha habido un cambio en ETA respecto a sus objetivos y eso es constatable desde el atentado a Ordóñez, hasta los de Aznar y Múgica e incluso el intento contra el Rey. Y yo diría, en términos ajedrecísticos, que ETA ya no mueve sus piezas hacia los peones para que se mueva el rey (el entrevistado por El Correo olvidaba los secuestros del momento), sino que está haciendo jaques a los alfiles del rey y al propio rey. Ese es un cambio que quizá pueda tener un valor añadido a esa reflexión sobre el próximo Gobierno. ETA está cambiando su táctica y no va hacia los peones para que se muevan las figuras, sino que va directamente hacia las figuras. En base a la constatación de esta realidad, decimos al próximo Gobierno que aquí tiene una alternativa democrática encima de la mesa y una voluntad de negociar de ETA para superar la situación. Ahí tiene una ocasión histórica para resolver definitivamente el conflicto» ${ }^{338}$.

\section{B) La crítica a los Partidos Políticos}

Hubo ciertamente crítica a los Partidos Políticos electorales, pero ésta se encuadró en el rechazo general de todo aquello, que se oponía al llamado Movimiento de Liberación Nacional Vasco. La crítica a los demás se justificó en la previa represión y persecución de Herri Batasuna, «en esta cruzada contra la izquierda abertzale en la que parece que todo vale para intentar hacer callar a HB y a las reivindicaciones políticas independentistas» ${ }^{339}$. La orientación del voto, según proclamaba la propaganda radical, sólo disponía de dos alternativas, o españolismo o abertzalismo de HB, ya que lo que existía era «el combate entre Euskal Herria y España» ${ }^{340}$. Supuesta esta simplificación, el rechazo de los defensores, promotores, apoyos e instrumentos de la primera alternativa fue universal.

\footnotetext{
337 El Correo 2-3-96 (22) y 28-2-96 (23).

338 El Correo 26-2-96 (19). Ver, también, El Correo 28-2-96 (23).

339 El Correo 17-2-96 (14).

340 El Correo 25-2-96 (34).
} 
Se criticó la Constitución española por su imposición del castellano y la francesa por la imposición del francés ${ }^{341}$; se denunció el «vacío democrático» de la campaña electoral, en la que «quienes defendemos la opción independentista vasca no nos encontramos en las mismas condiciones de igualdad que el resto» ${ }^{342}$, así como la dominación, sometimiento y represión que los Estados español y francés, «agresivos, violentos y reaccionarios», realizaban sobre el pueblo vasco ${ }^{343}$; se acusó a los bancos privados de dedicarse a la especulación y al robo, y a las Cajas vascas de no responder a las demandas de la población vasca; Banco de España y Gobiernos civil y militar decidían económicamente el futuro de Euskadi ${ }^{344}$ y en las imposiciones «desde fuera», es decir, España, estaban las causas del paro, la desindustrialización y el fraude fiscal ${ }^{345}$.

En la gran conjura contra el abertzalismo radical estaban los medios de comunicación social, tanto públicos como privados, la Policía, la Ertzaintza, los jueces y hasta los profesores de la Universidad del País Vasco firmantes de un manifiesto contra la violencia, para el que habían sido «comprados» con dinero público ${ }^{346}$.

No obstante esta represión política y social contra Herri Batasuna, de la que era una muestra la detención de Idígoras, K. Rodríguez respondía así a la pregunta de si «¿Ese clima no les da votos?»: «Yo creo que no tiene porque (sic) darnos votos. Desde luego, nunca hemos pensado que el victimismo sea un gancho electoral» ${ }^{347}$.

En este contexto general actuaban los partidos de ámbito estatal para «anular [la] identidad nacional vasca» ${ }^{348}$. Hasta la misma manifestación de Madrid en protesta por el asesinato de Tomás y Valiente fue interpretada como un acto partidista contra ETA y el movimiento independentis$\operatorname{ta}^{349}$. En las elecciones no pretendían otra cosa que «amarrar a Euskadi y

341 El Correo 20-2-96 (15). Ver también Deia 20-2-96 (6) y Egin 20-2-96 (13).

342 El Correo 2-3-96 (22).

343 El Correo 17-2-96 (14).

344 Ver El Correo 29-2-96 (25).

345 Ver El Correo 1-3-96 (25).

346 Ver El Correo 2-3-96 (22). Ver también El País 18-2-96 (19).

347 El Correo 26-2-96 (19).

348 El Correo 1-3-96 (25).

349 Ver El Correo 26-2-96 (19), donde el entrevistador, Juan Carlos Viloria, preguntaba a Karlos Rodríguez si a HB le había impresionado la manifestación de Madrid. K. Rodríguez respondió así a la pregunta: «La palabra no creo que sea impresionar. Desde luego, nos parece que desgraciadamente se hizo una utilización partidista y en plena campaña electoral todos los partidos se volcaron en demostrar que están dispuestos a acabar a (sic) ETA y con el movimiento independentista. Eso es lo que hemos visto en la manifestación. Y asociaciones como Víctimas del Terrorismo o personas afectadas por atentados han constatado su malestar por la diferenciación que se hace entre unos y otros». 
a la población vasca en una opción obligada: que tengamos que elegir entre "guatemala" y "guatepeor"», manifestó K. Landa ${ }^{350}$.

Para este trabajo los Partidos de ámbito general contaban con las formaciones políticas vascas. El coordinador general de LAB, Rafa Díez, criticó la «pasividad de un regionalismo acomodado a esta situación, resignado al poder cedido por el Gobierno central» ${ }^{351}$. Expresamente se añadiría que entre los españolistas y los abertzales estaban los colaboracionistas, que no eran otros que los Partidos Nacionalista Vasco y Eusko Alkartasuna. Entre todos habían organizado «la gran cruzada» contra el movimiento independentista ${ }^{352}$; estos Partidos «colaboracionistas» defendían «el proyecto de España con el PP, el PSOE o Izquierda Unida» y personajes como Arzalluz o Juan María Atutxa se habían subido «a la ola de ataque contra la izquierda abertzale» ${ }^{353}$. PNV y EA se sumaban a las fuerzas políticas que el 3 de marzo apoyarían el «voto a España» 354 .

Frente a todos y contra todos el responsable de las Gestoras pro Amnistía, Juan María Olano, había gritado en Anoeta: «(...) vamos bien y cada vez somos más y mejores» ${ }^{355}$.

\section{Universidad de Deusto}

Mayo de 1966

350 El Correo 2-3-96 (22).

351 El Correo 1-3-96 (25).

352 El Correo 25-2-96 (34). En El Correo 1-3-96 (25) se acusa a las formaciones vascas de apoyar el intento de «anular nuestra identidad nacional».

353 El Correo 272-2-96 (23).

354 El Correo 2-3-96 (22). La acusacion de «colaboracionismo» contra el PNV y EA aparece también en El Mundo del País Vasco 25-2-96 (36), Egin 27-2-96 (9) y Deia 27-2-96 (6).

355 Egin 25-2-96 (11). 